\title{
Methodiek arbeidsmarktprognoses en -indicatoren 2003-2008
}

Citation for published version (APA):

Cörvers, F., Dupuy, A., Dijksman, S., Golsteyn, B. H. H., \& Hensen, M. M. (2004). Methodiek

arbeidsmarktprognoses en -indicatoren 2003-2008. Researchcentrum voor Onderwijs en Arbeidsmarkt, Faculteit der Economische Wetenschappen. ROA Working Papers No. 2

https://doi.org/10.26481/umarow.2004002

Document status and date:

Published: 01/01/2004

DOI:

10.26481/umarow.2004002

Document Version:

Publisher's PDF, also known as Version of record

\section{Please check the document version of this publication:}

- A submitted manuscript is the version of the article upon submission and before peer-review. There can be important differences between the submitted version and the official published version of record.

People interested in the research are advised to contact the author for the final version of the publication, or visit the DOI to the publisher's website.

- The final author version and the galley proof are versions of the publication after peer review.

- The final published version features the final layout of the paper including the volume, issue and page numbers.

Link to publication

\footnotetext{
General rights rights.

- You may freely distribute the URL identifying the publication in the public portal. please follow below link for the End User Agreement:

www.umlib.nl/taverne-license

Take down policy

If you believe that this document breaches copyright please contact us at:

repository@maastrichtuniversity.nl

providing details and we will investigate your claim.
}

Copyright and moral rights for the publications made accessible in the public portal are retained by the authors and/or other copyright owners and it is a condition of accessing publications that users recognise and abide by the legal requirements associated with these

- Users may download and print one copy of any publication from the public portal for the purpose of private study or research.

- You may not further distribute the material or use it for any profit-making activity or commercial gain

If the publication is distributed under the terms of Article $25 \mathrm{fa}$ of the Dutch Copyright Act, indicated by the "Taverne" license above, 
Methodiek arbeidsmarktprognoses en -indicatoren 2003-2008

ROA-W-2004/2

F. Cörvers, A. Dupuy, S. Dijksman, B. Golsteyn, M. Hensen

Researchcentrum voor Onderwijs en Arbeidsmarkt

Faculteit der Economische Wetenschappen en Bedrijfskunde Universiteit Maastricht

Maastricht, juli 2004 
ISBN 90-5321-396-1

Sec04.081.doc 


\section{Inhoud}

Voorwoord

1 Inleiding

2 Structuur van de gepresenteerde arbeidsmarktinformatie

3 De actuele situatie op de arbeidsmarkt 4

3.1 Inleiding 4

3.2 De berekening van de trend 5

$\begin{array}{lll}3.3 \text { Toelichting op de variabelen voor de actuele arbeidsmarktsituatie } & 6\end{array}$

4 Methodiek arbeidsmarktprognoses 11

$\begin{array}{ll}4.1 \text { Inleiding } & 11\end{array}$

4.2 Methodiek uitbreidingsvraag 11

$\begin{array}{ll}4.3 \text { Methodiek vervangingsvraag } & 18\end{array}$

4.4 Methodiek instroom van schoolverlaters op de arbeidsmarkt 24

4.5 Baanopeningen en typering arbeidsmarktperspectieven $\quad 29$

4.6 Typering knelpunten in de personeelsvoorziening 30

5 De structurele arbeidsmarktsituatie $\quad 32$

5.1 Inleiding 32

$\begin{array}{ll}5.2 \text { Conjunctuurgevoeligheid } & 33\end{array}$

$\begin{array}{ll}5.3 \text { Uitwijk- en substitutiemogelijkheden } & 34\end{array}$

5.4 Concurrentie-index 35

$\begin{array}{ll}\text { Literatuur } & 35\end{array}$

$\begin{array}{ll}\text { Appendix A } & 39\end{array}$

$\begin{array}{ll}\text { Appendix B } & 41\end{array}$ 



\section{Voorwoord}

De weergave van de methodiek in dit werkdocument heeft betrekking op het samenstellen van de arbeidsmarktinformatie over 34 bedrijfssectoren, 127 beroepsgroepen en 104 opleidingstypen die is gebruikt in het rapport De arbeidsmarkt naar opleiding en beroep tot 2008. Dit rapport is in november 2003 uitgebracht in het kader van het Project OnderwijsArbeidsmarkt (POA) van het ROA. Het rapport biedt een overzicht van de huidige en toekomstige ontwikkelingen op de Nederlandse arbeidsmarkt in de periode 2003-2008. Het gepresenteerde overzicht heeft als doel inzicht te verschaffen in de actuele situatie en de prognoses van beroepen en opleidingen op de arbeidsmarkt. De prognoses worden elke twee jaar herhaald voor een nieuwe periode van vijf jaar. De beschrijvingen en analyses in het rapport spitsen zich toe op de grote lijnen van de huidige en toekomstige arbeidsmarktontwikkelingen.

In bijlage C van De arbeidsmarkt naar opleiding en beroep tot 2008 en op de website van het ROA (http://www.roa.unimaas.nl) wordt een overzicht van de beschikbare arbeidsmarktinformatie naar bedrijfssector, beroepsgroep en opleidingstype gegeven. Deze informatie is op aanvraag bij het ROA verkrijgbaar. Voor de financiers van POA is het zogenaamde ArbeidsmarktInformatieSysteem (AIS) beschikbaar, waarmee gebruikers zelf op eenvoudige wijze de gewenste tabellen kunnen samenstellen.

Het Project Onderwijs-Arbeidsmarkt wordt gefinancierd door het Ministerie van Onderwijs, Cultuur en Wetenschappen, het Centrum voor Werk en Inkomen, het LDC Expertisecentrum voor Loopbaanvraagstukken, de Raad voor Werk en Inkomen, de vereniging kenniscentra beroepsonderwijs bedrijfsleven COLO, de BVE Raad, het Ministerie van Landbouw, Natuur en Voedselkwaliteit en Randstad Nederland. 



\section{Inleiding}

In dit werkdocument wordt ingegaan op de databronnen, de definities van een aantal begrippen, en de prognosemethodiek die zijn gebruikt bij het rapport De arbeidsmarkt naar opleiding en beroep tot 2008 (ROA, 2003). In het rapport wordt reeds ingegaan op het doel van de arbeidsmarktprognoses, en een beknopte weergave van de gehanteerde methodiek met een beschrijving van de centrale begrippen gegeven. De uitgangspunten van het Project Onderwijs-Arbeidsmarkt en de prognosemethodiek zijn uitgebreider uiteengezet in verschillende andere publicaties. ${ }^{1}$ Voor een aantal specifieke onderdelen van de prognosemethodiek zijn tevens afzonderlijke werkdocumenten verschenen. Om die reden wordt in dit werkdocument voor deze aspecten slechts een globaal overzicht van de gehanteerde methodiek en het doel van de arbeidsmarktprognoses gegeven. Voor een meer gedetailleerde beschrijving wordt verwezen naar het op het desbetreffende onderdeel toegespitste werkdocument.

De arbeidsmarktprognoses naar opleiding en beroep vormen een belangrijk onderdeel van de beschikbare arbeidsmarktinformatie. In dit werkdocument wordt een actualisatie gegeven van de beschrijving van de prognosemethodiek in Cörvers e.a. (2002) bij de vorige uitgave De arbeidsmarkt naar opleiding en beroep tot 2006 (ROA, 2001). Van belang is op te merken dat de methodiek van het beroepenmodel van de uitbreidingsvraag geheel is vernieuwd. Bovendien wordt in paragraaf 4.5 van dit werkdocument een aparte toelichting op de methodiek van de baanopeningen gegeven.

De opzet van dit werkdocument is als volgt. In hoofdstuk 2 wordt de structuur van het informatiesysteem besproken. Vervolgens wordt in hoofdstuk 3 ingegaan op de actuele data in het informatiesysteem. In hoofdstuk 4 wordt de prognosemethodiek besproken en in hoofdstuk 5 wordt ingegaan op de indicatoren met betrekking tot de structurele kenmerken van de arbeidsmarkt.

\section{Structuur van de gepresenteerde arbeidsmarktinformatie}

Het doel van het Project Onderwijs-Arbeidsmarkt is om inzicht te verschaffen in de actuele en de op middellange termijn verwachte situatie op de arbeidsmarkt, verbijzonderd naar beroep en opleiding. Met dit transparant maken van de arbeidsmarkt wordt beoogd dat de bij onderwijs en arbeidsmarkt betrokken partijen beter inzicht hebben in de huidige en toekomstige ontwikkelingen in de aansluiting tussen onderwijs en arbeidsmarkt, zodat zij meer adequate beslissingen kunnen nemen. Hierdoor zullen discrepanties tussen vraag en aanbod op de arbeidsmarkt kunnen verminderen. Relevante betrokkenen zijn leerlingen, scholen, de overheid, de arbeidsvoorzieningsorganisatie en bedrijven. Door de verstrekte informatie kan een leerling die een studiekeuze maakt zich oriënteren op de arbeidsmarkt-

1. Zie o.a. Borghans, De Grip en Willems (1995), Van Eijs en De Grip (1998), De Grip en Heijke (1998), Borghans, De Grip en Heijke (2000), Cörvers, De Grip en Heijke (2002) en Cörvers (2003). 
perspectieven op het moment dat hij of zij de studie zal afronden, en krijgen aanbieders van onderwijs meer inzicht in de relevantie van hun opleidingenaanbod voor de verwachte vraag naar personeel op de middellange termijn. De structuur van de gegenereerde informatie sluit hierbij aan door voor zowel beroepen als voor opleidingen kengetallen te presenteren met betrekking tot de actuele situatie op de arbeidsmarkt en de arbeidsmarktsituatie over vijf jaar. Ook voor andere partijen die betrokken zijn bij het onderwijs is het van belang dat er vooruit wordt gekeken. Dit voorkomt een pro-cyclisch beleid, dat te sterk reageert op de actuele arbeidsmarktsituatie. Naast de perspectieven voor schoolverlaters zoals die zijn weergegeven in de Indicator Toekomstige Arbeidsmarktperspectieven (ITA), wordt ook ingegaan op het perspectief van de werkgever. Middels de Indicator Toekomstige Knelpunten in de Personeelsvoorziening (ITKP) en de Indicator Toekomstige Knelpunten in de Personeelsvoorziening naar Beroep (ITKB) wordt aangegeven voor welke opleidingstypen en beroepsgroepen wervingsproblemen te verwachten zijn.

Het arbeidsmarktinformatiesysteem van POA is opgebouwd uit drie componenten. De informatie over de actuele situatie geeft aan hoe thans de positie van werkenden en schoolverlaters met een bepaalde opleidingsachtergrond is. Het arbeidsmarktperspectief van de verschillende opleidingstypen geeft op grond van de verwachte kwantitatieve verschuivingen in vraag en aanbod aan hoe deze positie zich de komende vijf jaar zal ontwikkelen. Ten slotte plaatsen de structurele kenmerken van de arbeidsmarktpositie de positie van een bepaalde opleiding of beroep in een ruimer perspectief.

De actuele informatie is in principe gebaseerd op gerealiseerde gegevens over het jaar 2002 of het gemiddelde van de afgelopen twee jaren (2001-2002). ${ }^{2}$ Zo wordt een beeld gegeven van de absolute en relatieve omvang van het totaal aantal werkenden in een beroepsgroep en de omvang van de potentiële beroepsbevolking en het aantal werkenden met een bepaalde opleidingsachtergrond. Deze aantallen werkenden worden vervolgens ook verbijzonderd naar persoonlijke kenmerken als geslacht, etniciteit en leeftijd en naar de functiekenmerken: vast werk, deeltijdarbeid, e.d. Voor de onderscheiden opleidingstypen wordt bovendien getracht een beeld te geven van de actuele aansluitingsproblemen op de arbeidsmarkt, zowel wat betreft het percentage werkloze schoolverlaters, als de mate waarin er sprake is van onderbenutting.

Bij de middellangetermijnprognoses wordt zowel voor beroepsgroepen als opleidingstypen het verwachte aantal baanopeningen aangegeven. Deze vraag naar nieuwkomers is uitgesplitst naar de vraag als gevolg van nieuwe banen (uitbreidingsvraag) en de vervangingsvraag. Voor de opleidingen wordt daarnaast ook de instroom van nieuwkomers op de arbeidsmarkt voorspeld, zodat vraag en aanbod aan elkaar kunnen worden gerelateerd. Op basis van deze confrontatie en de substitutieprocessen die hierdoor op gang zullen komen, wordt een indicator van de verwachte arbeidsmarktsituatie voor de onder-

2. De gegevens over werkenden en schoolverlaters in het arbeidsmarktinformatiesysteem (AIS) worden jaarlijks geactualiseerd, in tegenstelling tot de prognosegegevens die tweejaarlijks worden geactualiseerd. Dit betekent dat de gegevens over werkenden en schoolverlaters in de loop van 2004 worden geactualiseerd. 
scheiden opleidingstypen opgesteld. Op vergelijkbare wijze worden ook de verwachte knelpunten in de personeelsvoorziening in kaart gebracht, waarbij bovendien per bedrijfssector de opleidingstypen met de grootste knelpunten worden aangeduid. Ook voor de beroepsgroepen wordt een indicator opgesteld van de verwachte knelpunten in de personeelsvoorziening.

De structurele kenmerken van de arbeidsmarktpositie zijn eveneens afgeleid uit gerealiseerde gegevens. Enerzijds verdiepen deze indicatoren het inzicht in de huidige arbeidsmarktpositie. Anderzijds zijn deze indicatoren een aanvulling op de prognoses, doordat ze aangeven in hoeverre een beroep c.q. opleiding afhankelijk is van de ontwikkeling in een enkele bedrijfssector of beroepsgroep, in hoeverre het beroependomein van een opleidingstype gerelateerd is aan het beroependomein van andere opleidingstypen en in welke mate de werkgelegenheid gevoelig is voor de conjuncturele ontwikkelingen. Op deze wijze fungeren deze indicatoren als risico-indicatoren.

Binnen het informatiesysteem worden de actuele data, de prognoses en de structurele kenmerken telkens op kwalitatieve wijze getypeerd. Met uitzondering van de indicatoren voor de toekomstige arbeidsmarktsituatie wordt hierdoor aangegeven wat op het desbetreffende punt de relatieve positie van het beroep of de opleiding is ten opzichte van de andere beroepen, respectievelijk opleidingen. Doorgaans vinden de typeringen plaats op basis van een vijf-puntsschaal, lopend van erg hoog, hoog, gemiddeld, laag, tot erg laag. De kwalitatieve typering zorgt ervoor dat de cijfers eenvoudiger zijn te interpreteren en dat schijnnauwkeurigheden worden vermeden. De typeringen hebben plaatsgevonden op basis van een methodiek beschreven in Wieling, De Grip en Willems (1990). Daarbij wordt tevens enigszins van deze procedure afgeweken door de berekende grenzen tussen de typeringsintervallen af te ronden. In appendix A wordt voor alle variabelen in het informatiesysteem aangegeven welke grenzen zijn gehanteerd bij de kwalitatieve typering.

Bij de gepresenteerde informatie per beroepsgroep en opleidingstype wordt er ook een expliciete relatie gelegd tussen beroepen en opleidingen. Per opleidingstype wordt een overzicht gegeven van de belangrijkste beroepsgroep waarin men werkzaam is en voor elke beroepsgroep wordt de opleidingsachtergrond van de werkenden in beeld gebracht. Een vergelijkbare relatie is ook gelegd tussen bedrijfssectoren en beroepsgroepen of opleidingstypen.

Voor gebruikers van de arbeidsmarktinformatie is het doorgaans wenselijk om de beroepen en de opleidingen op een zo gedetailleerd mogelijk niveau in beeld te brengen. Deze detaillering kent echter haar grenzen in de beschikbaarheid van de basisgegevens, die voor een groot deel afkomstig zijn uit de Enquête Beroepsbevolking (EBB) van het Centraal Bureau voor de Statistiek (CBS). De onzekerheidmarges waarmee de EBB-cijfers zijn omgeven leggen een ondergrens op aan de mate van detaillering die in het informatiesysteem voor beroepen en opleidingen kan worden toegepast. Voor de EBB-gegevens geldt een ondergrens voor de aantallen personen die in de tabellen gepubliceerd mogen worden. Voor jaarcijfers is dat minimaal 5.000 werkenden, voor meerjaarsgemiddelden is dat minimaal 2.500 werkenden. Ook kunnen gegevens worden gepubliceerd die gebaseerd zijn 
op een randtotaal van 30.000 werkenden voor één jaar en 15.000 werkenden voor het gemiddelde van twee jaren Waar deze ondergrens niet werd bereikt wordt in de overzichtstabellen het betreffende getal met een '-' aangegeven. Andere belangrijke informatiebronnen zijn de schoolverlatersenquêtes RUBS, HBO-Monitor en de WO-Monitor, welke tezamen beschikbaar zijn in het SchoolverlatersInformatieSysteem (SIS, zie ROA 2003a). Bij de presentatie van gegevens uit deze databestanden is een ondergrens van 15 respondenten gehanteerd.

Voor de bruikbaarheid van de prognoses, actuele informatie en indicatoren is het van belang dat de gehanteerde opleidingsindeling zo goed mogelijk aansluit bij de op de arbeidsmarkt bestaande deelmarkten. Heijke, Matheeuwsen en Willems (2003) hebben daarom de opleidingsrichtingen vanuit een arbeidsmarktperspectief geclusterd. Er worden thans 113 opleidingstypen onderscheiden, die gekoppeld zijn aan de Standaard Onderwijsindeling 1978 (SOI '78) van het CBS. In totaal wordt voor 104 opleidingstypen actuele informatie en arbeidsmarktprognoses verstrekt. De gegevens met betrekking tot het MBO-niveau uit zowel de EBB als de schoolverlatersenquêtes zijn gebaseerd op de in de Wet Educatie en Beroepsonderwijs (WEB) onderscheiden leerwegen. ${ }^{3}$ Appendix $B$ bevat een overzicht van de recente wijzigingen in de opleidingsnamen.

Voor de arbeidsmarktinformatie naar beroep is gebruik gemaakt van de Standaard Beroepenclassificatie 1992 (SBC '92) van het CBS. Hierdoor wordt de vergelijkbaarheid met andere informatiebronnen over de arbeidsmarkt sterk vergroot. Omdat het CBS de beroepsgroepen aanduidt met vrij abstracte termen, heeft het ROA wel andere benamingen voor deze beroepsgroepen gehanteerd. Uitgangspunt hierbij is dat de namen kort en herkenbaar moeten zijn, en daarnaast een zo groot mogelijk deel van de onderliggende beroepen, gemeten in het aantal werkzame personen, gerepresenteerd moet worden. Op een aantal punten is de CBS-classificatie verder verbijzonderd. De door het CBS onderscheiden elementaire beroepen zijn opgesplitst in zes beroepsgroepen. Ook de beroepsgroep 471 middelbare procestechnische beroepen was dermate heterogeen dat deze is opgesplitst in 471a procesoperators en 471b bakkers en slagers. In De arbeidsmarkt naar opleiding en beroep tot 2004 werden reeds een tweetal beroepsgroepnamen gewijzigd. In appendix $\mathrm{B}$ zijn deze wijzigingen vermeld. Overigens worden in de ROA-classificatiegids 2002 (ROA, 2002) uitgebreide overzichten gegeven van de namen en coderingen van de sectoren, beroepen en opleidingen die binnen POA gehanteerd worden en de koppelingen tussen de classificaties naar opleiding, beroep en sector van het CBS en het ROA.

\section{De actuele situatie op de arbeidsmarkt}

\subsection{Inleiding}

In dit hoofdstuk wordt een overzicht gegeven van de gegevens in het informatiesysteem met betrekking tot de actuele arbeidsmarktpositie vanuit de invalshoek van bedrijfssectoren,

3. Zie voor een toelichting op de opleidingbenamingen in de WEB en het VMBO Bijlage $B$ in De arbeidsmarkt naar opleiding en beroep tot 2004 (ROA, 1999). 
beroepsgroepen en opleidingstypen. De gegevens die betrekking hebben op de gehele werkzame beroepsbevolking zijn gebaseerd op de Enquête Beroepsbevolking (EBB) van het CBS. De gegevens hebben betrekking op het gemiddelde aantal werkenden in de jaren 2001 en 2002. Naast de informatie over de actuele arbeidsmarktpositie van de werkzame beroepsbevolking naar opleiding, wordt er aanvullende informatie gegeven over de positie van schoolverlaters. Deze schoolverlatersinformatie is gebaseerd op de schoolverlatersenquêtes RUBS, de HBO-Monitor en de WO-Monitor, welke geïntegreerd zijn in het SchoolverlatersInformatieSysteem (SIS) van het ROA. Voor het AVO, VBO en MBO is gebruik gemaakt van RUBS 2002, terwijl de gegevens over het HBO en het WO gebaseerd zijn op respectievelijk de HBO-Monitor 2002 en WO-Monitor 2002 (zie ook ROA, 2003a). In deze schoolverlatersenquêtes zijn in het najaar van 2002 over de volle breedte van het onderwijsstelsel schoolverlaters en afgestudeerden geënquêteerd ongeveer anderhalf jaar na het voltooien van hun opleiding (schooljaar 2000/2001).

Naast de in hoofdstuk 2 genoemde kwalitatieve typering van de verschillende cijfers, wordt voor de actuele data in de meeste gevallen ook de ontwikkeling (trend) van de desbetreffende cijfers getypeerd, variërend van sterk dalend tot sterk stijgend. Alvorens in te gaan op de actuele data die gepresenteerd zijn in De arbeidsmarkt naar opleiding en beroep tot 2008 en het bijbehorende ArbeidsmarktInformatieSysteem (AIS), wordt in de volgende paragraaf ingegaan op de bepaling van deze trends.

\subsection{De berekening van de trend}

Uitgangspunt van de methodiek om de trend vast te stellen is een exponentieel model dat wordt geschat en waarin de ontwikkeling van $x_{t}$ wordt verklaard uit een constante term $\alpha$ en een trendvariabele $t, t=1, \ldots, n$ :

$\ln \left(x_{t}\right)=\alpha+\beta t$

De OLS-schatting voor $\beta$ vormt de trend-indicator. Omdat de (natuurlijke) logaritme van de te verklaren variabele is genomen in de vergelijking kan deze indicator geïnterpreteerd worden als de jaarlijkse procentuele groei. De expliciete vergelijking maakt het mogelijk deze trend ook te berekenen voor tijdreeksen met een ontbrekende waarneming. De interpretatie van de indicator is onafhankelijk van de gehanteerde reeks. Wel blijken korte tijdreeksen over het algemeen sterkere trends te vertonen dan langere reeksen. Bij de langere reeksen vallen tegengestelde bewegingen immers tegen elkaar weg.

Op basis van een analyse van de trends is vastgesteld dat een trendberekening op basis van een vijjarige tijdreeks het meest geschikt is. Bij het bepalen van de trends is derhalve uitgegaan van de ontwikkelingen in de jaren 1998-2002.

De OLS-schatter voor $\beta$ is voor een reeks van vijf jaren de facto gelijk aan: 
$\hat{\beta}=-\frac{2}{10} \ln \left(x_{1}\right)-\frac{1}{10} \ln \left(x_{2}\right)+\frac{1}{10} \ln \left(x_{4}\right)+\frac{2}{10} \ln \left(x_{5}\right)$

Naast de trendschatting zelf is ook de standaarddeviatie van de geschatte trend berekend. Tijdreeksen met een grillig verloop kunnen per toeval een zeer sterke trendwaarde opleveren. De trend wordt daarom niet meer gepresenteerd als de standaarddeviatie $(s d)$ te groot is:

$\left|\frac{\text { trend }}{s d}\right|<1$

Evenals de actuele data, de structurele gegevens en de prognoses zijn ook de trendmatige ontwikkelingen kwalitatief getypeerd. Voor elke variabele is dezelfde indeling gehanteerd.

$$
\begin{array}{rlll} 
& \text { trend } \leq-0,10 & \text { sterk dalend } \\
-0,10< & \text { trend } \leq-0,03 & \text { dalend } \\
-0,03< & \text { trend } \leq 0,03 & \text { constant } \\
0,03< & \text { trend } \leq 0,10 & \text { stijgend } \\
0,10< & \text { trend } & & \text { sterk stijgend }
\end{array}
$$

De trendwaarden kunnen rechtstreeks geïnterpreteerd worden als gemiddelde jaarlijkse groei. Overigens dient opgemerkt te worden dat de trend betrekking kan hebben op zowel de absolute waarde (bijv. het aantal werkenden), als de relatieve omvang van een variabele (bijv. het percentage allochtonen van de werkzame beroepsbevolking). In de volgende paragrafen zal bij iedere variabele worden aangegeven welke invalshoek is gehanteerd bij het vaststellen van de trend.

\subsection{Toelichting op de variabelen voor de actuele arbeidsmarktsituatie}

In deze paragraaf wordt een technische toelichting gegeven op de variabelen die in het informatiesysteem van het Project Onderwijs-Arbeidsmarkt (POA) zijn opgenomen voor een beschrijving van de actuele situatie op de arbeidsmarkt. ${ }^{4}$ In tabel 3.1 zijn de definities van de variabelen weergegeven. Daarnaast wordt in de tabel aangegeven op welke indeling deze variabele betrekking heeft, i.e. naar bedrijfssector, beroepsgroep of opleidingstype, en uit welke bron de gegevens afkomstig zijn. Deze bron kan betrekking hebben op zowel de Enquête Beroepsbevolking (EBB) van het CBS als het SchoolverlatersInformatieSysteem (SIS) van het ROA. Voor de variabelen waarvoor een trend is vastgesteld, wordt aangegeven of de trend gebaseerd is op de ontwikkeling van de absolute aantallen werkzame personen of het werkgelegenheidsaandeel.

4. Zie paragraaf 5 voor een toelichting op de variabelen die betrekking hebben op de structurele arbeidsmarktsituatie, i.e. de conjunctuurgevoeligheid, de uitwijk- en substitutiemogelijkheden en de concurrentie-index. 
Tabel 3.1

Technische toelichting op de variabelen over de actuele situatie op de arbeidsmarkt

$\begin{array}{ll}\text { Aantal werkenden } & \begin{array}{l}\text { Het aantal werkenden heeft betrekking op iedereen die jonger is dan } \\ \text { en minstens } 12 \text { uur per week werkt. }\end{array} \\ \begin{array}{l}\text { beschikbaar voor } \\ \text { bron }\end{array} & \begin{array}{l}\text { EBdrijfsector, beroepsgroep, opleidingstype } \\ \text { trend }\end{array} \\ \text { ja, absolute aantallen werkenden } \\ \text { Arbeidsvolume } & \begin{array}{l}\text { Arbeidsvolume is het totaal aantal normaal gewerkte arbeidsuren } \\ \text { gedeeld door } 40\end{array} \\ \text { beschikbaar } & \text { bedrijfssector, beroepsgroep, opleidingstype } \\ \text { bron } & \text { EBB } \\ \text { trend } & \text { Nee }\end{array}$

\section{Arbeidsmarktpositie potentiële beroepsbevolking}

De potentiële beroepsbevolking betreft alle mensen die ouder zijn dan 15 en jonger dan 64, uitgezonderd studenten/ scholieren in het regulier onderwijs. Het percentage werkloos is de werkloze beroepsbevolking als percentage van de potentiële beroepsbevolking, hetgeen niet verward moet worden met het gebruikelijke werkloosheidspercentage waarin de werkloosheid gerelateerd wordt aan de beroepsbevolking.

Opleidingstype

EBB

Nee

Alle niet werkzame personen die binnen twee weken in een nieuwe werkkring kunnen beginnen.

Opleidingstype

EBB

Nee

Niet beschikbare nietparticiperende beroepsbevolking

beschikbaar

bron

trend

Alle niet werkzame personen die niet binnen twee weken in een nieuwe werkkring kunnen beginnen.

\section{Opleidingstype}

Nee

\section{Participatie schoolverlaters in vervolgopleidingen}

beschikbaar

bron

trend

In de Wet Educatie en Beroepsonderwijs (WEB) waarin de nieuwe kwalificatiestructuur voor het MBO is vastgelegd, wordt onderscheid gemaakt tussen de beroepsopleidende en beroepsbegeleidende leerweg (BBL). Deze laatste is vergelijkbaar met het oude leerlingwezen.

Opleidingstype

SIS

Nee 
Tabel 3.1 (vervolg)

Technische toelichting op de variabelen over de actuele situatie op de arbeidsmarkt

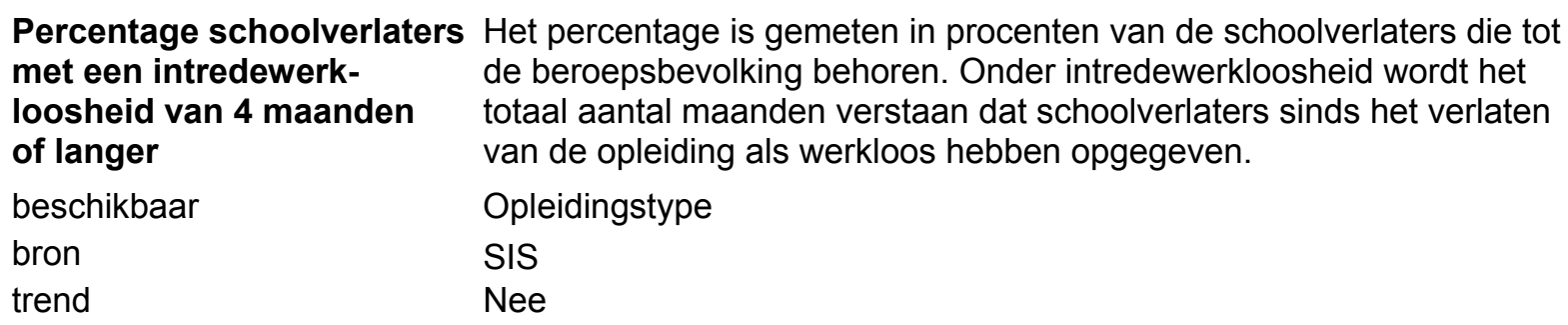

\section{Percentage werkloze schoolverlaters}

beschikbaar

bron

trend

Percentage vrouwen

beschikbaar

bron

trend

Percentage niet-westerse allochtonen

beschikbaar

bron

trend Percentage jongeren en
ouderen

beschikbaar

bron

trend

\section{Gemiddelde leeftijd}

beschikbaar

bron

trend

Percentage deeltijdarbeid

beschikbaar

bron

trend
Het percentage is gemeten in procenten van de schoolverlaters die tot de beroepsbevolking behoren. De definities van werkloosheid en beroepsbevolking zijn dezelfde als van het CBS.

opleidingstype

SIS

nee

bedrijfssector, beroepsgroep, opleidingstype

EBB

ja, werkgelegenheidsaandeel

Het percentage allochtonen naar herkomst heeft betrekking op iedereen waarvan ten minste één ouder in het buitenland is geboren. Tot de niet-westerse herkomstlanden worden gerekend Turkije en alle landen in Afrika, Latijns-Amerika en Azië (met uitzondering van Japan en Indonesië).

bedrijfssector, beroepsgroep, opleidingstype

EBB

nee, te weinig jaren om een trend te bepalen

De jongeren betreft alle mensen die ouder dan 15 jaar en jonger dan 30 jaar zijn. Voor de ouderen geldt dat ze ouder dan 50 jaar en jonger dan 64 jaar zijn.

bedrijfssector, beroepsgroep, opleidingstype

EBB

ja, werkgelegenheidsaandeel

beroepsgroep, opleidingstype

EBB

nee

Deeltijdarbeid betreft personen die hoogstens 32 uur maar minstens 12 uur per week werkzaam zijn.

bedrijfssector, beroepsgroep, opleidingstype

EBB

ja, werkgelegenheidsaandeel 
Tabel 3.1 (vervolg)

Technische toelichting op de variabelen over de actuele situatie op de arbeidsmarkt

Percentage deeltijdarbeid Deeltijdarbeid betreft de schoolverlaters die hoogstens 32 uur maar onder schoolverlaters minstens 12 uur per week werkzaam zijn.

beschikbaar

opleidingstype

bron

SIS

trend

nee

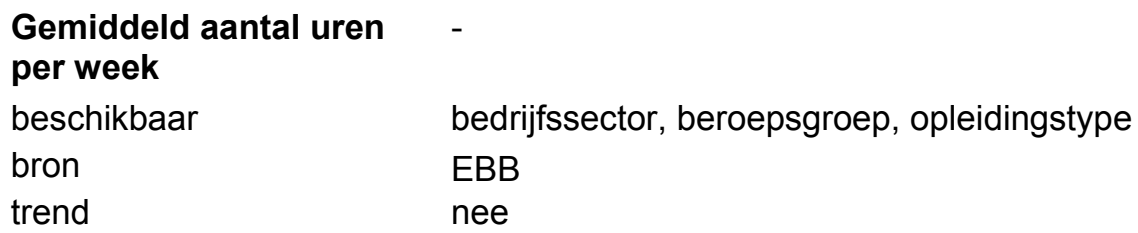

Percentage flexibel werk Van een flexibele arbeidsrelatie is sprake bij uitzendkrachten, oproepkrachten, invalskrachten en contracten zonder een vast aantal arbeidsuren en indien geen vast dienstverband is overeengekomen. Een arbeidscontract wordt als niet-vast beschouwd als de contractuele termijn korter is dan een jaar en er geen vooruitzicht is op een vast dienstverband.

beschikbaar

bedrijfssector, beroepsgroep, opleidingstype

bron

EBB

trend

ja, werkgelegenheidsaandeel

Percentage vast werk

beschikbaar

bedrijfssector, beroepsgroep, opleidingstype

bron

EBB

trend

ja, werkgelegenheidsaandeel

\section{Percentage werkzame schoolverlaters met vast dienstverband}

beschikbaar

opleidingstype

bron

SIS

trend

nee

Percentage zelfstandigen Het begrip zelfstandig bevat ook personen die werkzaam zijn in het bedrijf of de praktijk van hun partner of ouders en freelancers e.d.

beschikbaar

bedrijfssector, beroepsgroep, opleidingstype

bron

EBB

trend

ja, werkgelegenheidsaandeel 
Tabel 3.1 (vervolg)

Technische toelichting op de variabelen over de actuele situatie op de arbeidsmarkt

Gemiddeld bruto maand- Dit bruto maandloon is samengesteld op basis van een voltijdaanstelling. loon van werkzame schoolverlaters

beschikbaar
bron
trend
Percentage werkzame
schoolverlaters met
functie buiten de
vakrichting
beschikbaar
bron
trend
Percentage werkzame
schoolverlaters van wie
kwalificaties worden
onderbenut

beschikbaar

bron

trend

Belangrijkste
beroepsgroepen

beschikbaar

bron

trend

\section{Belangrijkste bedrijfssectoren}

beschikbaar

bron

trend

Belangrijkste opleidingstypen

beschikbaar

bron

trend

\author{
opleidingstype \\ schoolverlatersenquêtes \\ nee
}

De functie is een functie buiten de eigen vakrichting wanneer voor de functie de eigen of een verwante opleidingsrichting niet vereist is.

\author{
opleidingstype \\ SIS
}

nee

Onderbenutting wordt bepaald op basis van het opleidingsniveau dat vereist is voor de functie.

opleidingstype

SIS

nee

Hierin zijn alle beroepsgroepen opgenomen die ten minste betrekking hebben op $5 \%$ van de totale werkgelegenheid in de desbetreffende bedrijfssector/opleidingstype.

bedrijfssector, opleidingstype

EBB

ja, werkgelegenheidsaandeel

Hierin zijn alle bedrijfssectoren opgenomen die ten minste betrekking hebben op $5 \%$ van de totale werkgelegenheid in de desbetreffende beroepsgroep/opleidingstype.

beroepsgroep, opleidingstype

EBB

ja, werkgelegenheidsaandeel

Hierin zijn alle opleidingstypen opgenomen die ten minste betrekking hebben op $5 \%$ van de totale werkgelegenheid in de desbetreffende bedrijfssector/beroepsgroep.

bedrijfssector, beroepsgroep

EBB

ja, werkgelegenheidsaandeel 


\section{Methodiek arbeidsmarktprognoses}

\subsection{Inleiding}

In dit hoofdstuk wordt ingegaan op de gehanteerde onderzoeksmethoden van de middellangetermijnprognoses naar beroepsgroep en opleidingstype voor de periode 20032008. In de inleiding 'Doel en opzet van de arbeidsmarktprognoses' van De arbeidsmarkt naar opleiding en beroep tot 2008 wordt een globaal overzicht gegeven van het prognosemodel van het informatiesysteem. Dit algemene overzicht zal hier niet worden herhaald, maar aansluitend daarop zal meer specifiek op de verschillende prognoseonderdelen worden ingegaan. Achtereenvolgens zal de methodiek van de uitbreidingsvraagprognose, de prognose van de vervangingsvraag en de prognose van de toekomstige instroom van nieuwkomers op de arbeidsmarkt worden besproken. Ten slotte wordt een toelichting gegeven op de totstandkoming van de samenvattende indicatoren van aan de ene kant de arbeidsmarktperspectieven per opleidingstype (incl. bespreking van baanopeningen), en aan de andere kant de verwachte knelpunten in de personeelsvoorziening per opleidingstype en per beroepsgroep.

\subsection{Methodiek uitbreidingsvraag}

Op basis van het Athena-model (CPB, 1990) maakt het CPB prognoses van de werkgelegenheidsontwikkeling per bedrijfstak. ${ }^{5}$ Deze werkgelegenheidsprognoses vormen het startpunt van de prognoses van de uitbreidingsvraag naar beroepsgroep en opleidingstype. De prognoses van de uitbreidingsvraag tot 2008 zijn gebaseerd op het 'voorzichtige' scenario van de werkgelegenheidsramingen voor bedrijfssectoren van het Centraal Planbureau (CPB) in de publicatie Economische Verkenning 2003 - 2006 van december 2001. Het CPB heeft tevens, in het verlengde van deze ramingen, een werkgelegenheidsprojectie gemaakt voor de verschillende bedrijfssectoren van 2006 tot 2010 . In afwijking van deze middellangetermijnramingen voor de jaren tot 2008 is voor de bedrijfssectorprognoses van de uitbreidingsvraag voor 2003 en 2004 gebruik gemaakt van het Centraal Economisch Plan 2003 (CEP) van het CPB. Door het gebruik van deze kortetermijnprognoses worden de gehanteerde middellangetermijnramingen gecorrigeerd met de meer recente inzichten van de groeiverwachtingen volgens het CEP. De arbeidsvolume-prognoses van het CPB zijn met behulp van prognoses van de P/A-ratio's van het CPB omgerekend naar werkzame personen. De procentuele ontwikkelingen en de prognoses van het aantal werkenden in het informatiesysteem worden weergegeven ten opzichte van het aantal werkenden in het basisjaar 2002 volgens de Enquête Beroepsbevolking (EBB) van het CBS.

In aansluiting op de prognoses van de uitbreidingsvraag voor bedrijfssectoren worden door het ROA prognoses gemaakt van de verschuivingen in de beroepenstructuur binnen de

5. Hieronder worden de benamingen 'bedrijfstakken' (CPB-term) en 'bedrijfssectoren' (zie ROA, 2002) door elkaar gebruikt. 
onderscheiden bedrijfssectoren. Hierdoor kan er rekening gehouden worden met het feit dat binnen een bedrijfssector bepaalde beroepsgroepen zich sneller ontwikkelen dan andere. Voorts zijn er in het zogenaamde beroepenmodel van de uitbreidingsvraag, naast de trend van de werkgelegenheid, verschillende verklarende variabelen gebruikt om de prognoses van de uitbreidingsvraag naar beroep samen te stellen (zie hieronder).

Figuur 4.1

Overzicht van de totstandkoming van de prognoses naar beroepsgroep en opleidingstype

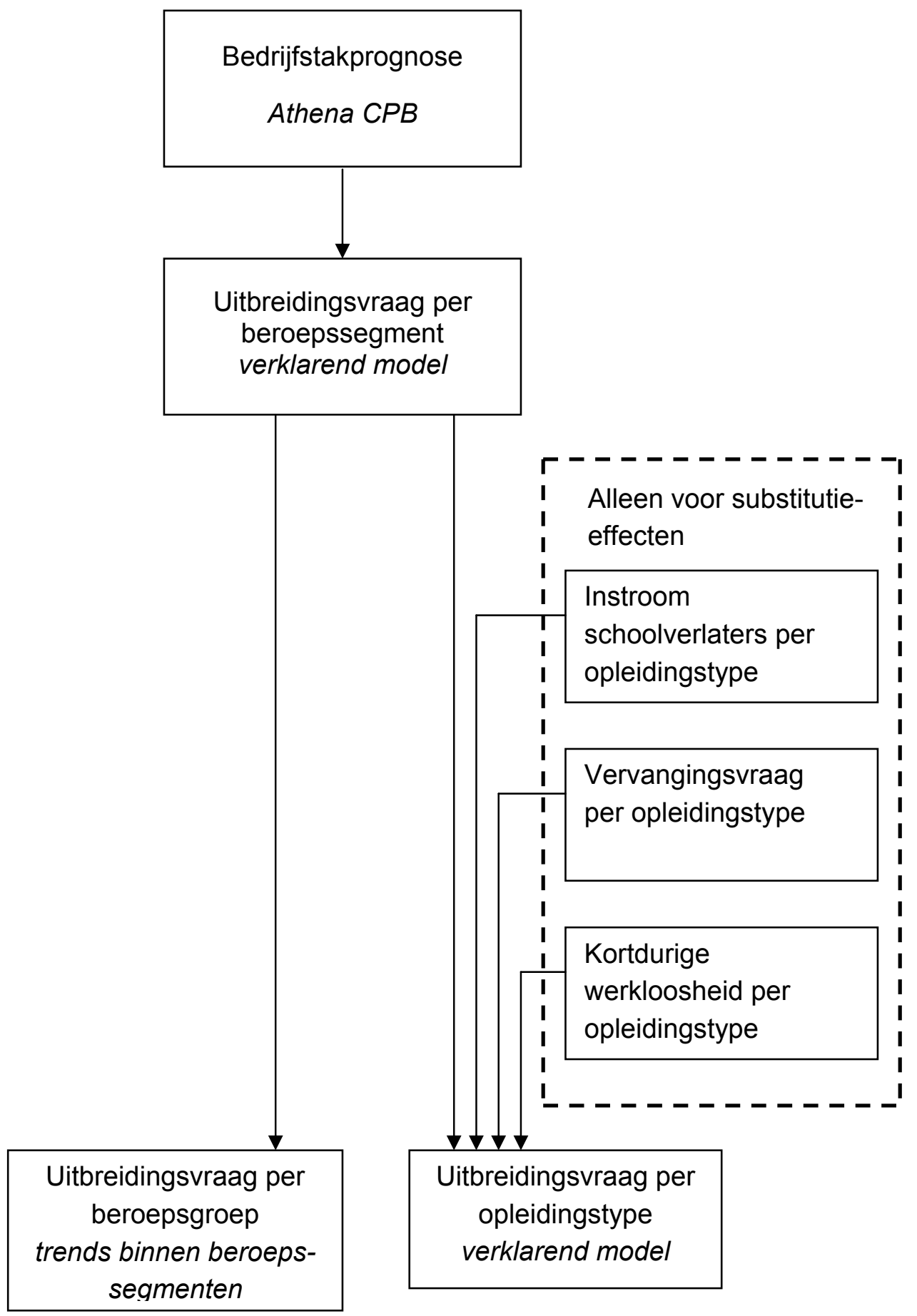


In figuur 4.1 staat aangegeven hoe de prognoses van de werkgelegenheidsontwikkeling voor beroepen en opleidingen tot stand komen. Vanuit de bedrijfssectorprognoses wordt een prognose opgesteld voor beroepssegmenten. Vervolgens vindt er vanuit de werkgelegenheidsprognoses per beroepssegment een verdere uitsplitsing plaats naar de beroepsgroepen. De beroepenindeling is gebaseerd op de Standaard Beroepen Classificatie uit 1992 (SBC '92) van het CBS (1993). De beroepssegmenten zijn gebaseerd op de indeling op 2-digit-niveau; de beroepsgroepen op de indeling op 3-digit-niveau. ${ }^{6} \mathrm{Er}$ worden in totaal 43 beroepssegmenten en 127 beroepsgroepen onderscheiden. ${ }^{7}$

De prognoses van de werkgelegenheidsontwikkelingen per beroepssegment vormen de basis voor de prognoses van de uitbreidingsvraag per opleidingstype. In het opleidingenmodel vindt een confrontatie plaats tussen vraag en aanbod, waardoor ook de invloeden op de vraag die veroorzaakt worden door overschotten of tekorten in aanverwante studierichtingen in het model konden worden opgenomen. Hiervoor zijn de prognoses van de arbeidsmarktinstroom van schoolverlaters en de vervangingsvraag en de informatie over de kortdurige werkloosheid per opleidingstype aan het begin van de prognoseperiode noodzakelijke invoergegevens voor het model.

\section{Het beroepenmodel}

In het beroepenmodel wordt de voorspelde werkgelegenheidsontwikkeling per bedrijfstak omgezet naar de werkgelegenheidsontwikkeling per beroepssegment en beroepsgroep. Hierbij wordt de veronderstelling gemaakt dat de werkgelegenheid per beroepsgroep volledig door de vraagzijde van de markt bepaald wordt. De ontwikkelingen in de vraag per beroepsgroep worden bepaald door de werkgelegenheidsverschuivingen tussen bedrijfssectoren en de veranderingen in de beroepenstructuur van de werkgelegenheid per bedrijfssector.

De uitbreidingsvraag naar beroep is geschat met EBB-data van 1987 tot en met 2002. Het gaat bij deze werkgelegenheidscijfers om werkzame personen die een werkverband van minstens 12 uren per week hebben. Het CBS is vanaf 1994 over gegaan op een nieuwe bedrijfssectorindeling. Om toch de EBB gegevens voor de periode 1987 tot en met 1993 te kunnen gebruiken is een schatting gemaakt van aantallen werkenden per bedrijfssector volgens de nieuwe indeling. Dit was mogelijk omdat in 1994 zowel de oude als de nieuwe classificatie gehanteerd zijn. De verhoudingen van de aantallen werkenden per beroepssegment per bedrijfssector volgens de oude en nieuwe indeling in dat jaar zijn dus bekend.

6. Bij de beroepsgroepindeling zijn, zoals reeds eerder is opgemerkt, de elementaire beroepen opgesplitst in zes beroepsgroepen, terwijl de middelbare procestechnische beroepen (code 471) verder zijn opgesplitst in de beroepsgroepen procesoperators en bakkers en slagers.

7. Zie de 2-digitcodes en bijbehorende benamingen in de ROA-classificatiegids (ROA, 2002, tabel 6 en 7). 
Verder zijn in de EBB-matrices beroepssegment $x$ bedrijfssector de aantallen beneden de CBS-ondergrens gelijkgesteld aan 0 . Hierdoor verdwijnen in iedere bedrijfssector een aantal kleinere beroepssegmenten. Beroepssegmenten die voor één of meerdere jaren niet voorkomen in de tijdreeks zijn weggelaten. In totaal zijn er 217 combinaties van beroepssegmenten en bedrijfssectoren waarvoor de werkgelegenheidsontwikkeling is geschat.

De beroepenstructuur binnen bedrijfssectoren wordt geschat aan de hand van een nieuw model van Dupuy en Cörvers (2003). ${ }^{8}$ In dit model spelen, behalve de tijdtrend, vier factoren een rol bij de verklaring van de veranderingen in de vraag naar beroepen binnen bedrijfssectoren. De beroepenstructuur binnen bedrijfssectoren wordt bepaald door het productieniveau ('non-homothetic production function') per bedrijfssector, de kapitaalintensiteit per bedrijfssector ('capital-skill complementarity'), het gebruik van nieuwe meer kennisintensieve technologieën ('skill biased technological change') en de relatieve lonen op de verschillende arbeidsmarktsegmenten. Om het model te schatten zijn voor de 13 verschillende bedrijfssectoren data verzameld over de toegevoegde waarde, de investeringen in kapitaal, de loonsom en de investeringen in Research and Development (R\&D) tussen 1987 en 2002. De benodigde data zijn ontleend aan de zogenaamde 'Lange Reeksen' van het CPB. Deze reeksen zijn gebaseerd op de Nationale Rekeningen van het CBS, en worden door het CPB gebruikt als data-input voor de schattingen van de vergelijkingen in het Athena-model. Alleen de R\&D-gegevens zijn direct afkomstig van het CBS (via Statline), en zijn gebaseerd op de R\&D- en innovatie-enquêtes van het CBS onder bedrijven, research-instellingen en universiteiten.

In de eerste stap van de schattingsprocedure is getoetst of de verschillende tijdreeksen al dan niet stationair zijn, dat wil zeggen er is gekeken naar de significantie van een stochastische of deterministische trend in de werkgelegenheidsontwikkeling van de beroepssegmenten per bedrijfssector en de bovengenoemde vier verklarende variabelen. De 'unit root'-testen wijzen uit dat er bijna altijd sprake is van een stochastische trend. Tevens is er in meer dan driekwart van de tijdreeksen een significante deterministische trend. Uit de resultaten van de empirische toetsing kan geconcludeerd worden dat alle tijdreeksen non-stationair en geïntegreerd van de eerste orde zijn. Derhalve wordt er getoetst of er sprake is van coïntegratie tussen de werkgelegenheidsaandelen van beroepssegmenten per bedrijfssector en de verklarende sectorvariabelen.

In de test op coïntegratie wordt gekeken naar de afwijking van het aandeel van de werkgelegenheid van een beroepssegment in een bedrijfssector van het geschatte langetermijnverband (zie de 'error correctie' term in vgl. 4.1). Het blijkt dat de residuen stationair zijn voor meer dan driekwart van de combinaties van beroepssegment en bedrijfssector. Voor de werkgelegenheidsaandelen van beroepssegment $j$ in bedrijfssector $i$,

8. Het oude model was gebaseerd op Borghans en Heijke (1994). Zij gebruikten een randomcoëfficiënten-model met verklarende variabelen uit het Athena-model. Zij deden de aanbeveling om nader onderzoek te verrichten naar variabelen waarmee de werkgelegenheidsontwikkeling naar beroep beter verklaard en voorspeld kan worden. 
weergegeven door $l_{i j, t}$, worden daarom aan de hand van de betreffende tijdreeksen van 1987-2002 $(t)$ de volgende vergelijkingen geschat volgens de 'error correctie' specificatie zoals voorgesteld door Engle en Granger (1987):

$\Delta l_{i j, t}=\alpha_{i j}+\sum_{k} \lambda_{k i j} \Delta x_{k i, t}+\gamma_{i j} \sum_{k}\left(l_{i j, t-1}-\beta_{k i j} x_{k i, t-1}\right)+\varepsilon_{i j, t}^{*}$

waarbij $x_{k i, t}$ de verklarende variabelen $k$ per bedrijfssector $i$ representeren, en $\varepsilon_{i j, t}^{*}$ is een storingsterm. $\alpha_{i j}$ en $\lambda_{k i j}$ zijn de parameters voor respectievelijk de constante en de $k$ verklarende variabelen $(k=4)$. Bovendien geven de parameters $\gamma_{i j}$ en $\beta_{k i j}$ de effecten weer van respectievelijk de afwijkingen van het langetermijnevenwicht (de 'error correctie') en de verklarende variabelen $k$ op de werkgelegenheidsaandelen van beroepssegment $j$ in bedrijfssector $i$. Het 'error correctie' mechanisme is in ongeveer $90 \%$ van de combinaties van bedrijfssectoren en beroepssegmenten statistisch significant.

Voor de prognose van de werkgelegenheidsaandelen van beroepssegmenten binnen bedrijfssectoren is gebruik gemaakt van de eerder genoemde Athena-prognoses van het CPB. Het betreft hier niet alleen de prognoses van de werkgelegenheid naar bedrijfstak, maar ook de bedrijfstakprognoses voor de toegevoegde waarde, de investeringen in kapitaal en de loonsom. De prognoses van de investeringen in R\&D zijn gebaseerd op een extrapolatie van de tijdreeksen van het CBS. De bedrijfstakprognoses van de werkgelegenheid van het CPB (zie hierboven) en de prognoses van de veranderingen in de werkgelegenheidsaandelen van beroepssegmenten binnen bedrijfssectoren zijn toegepast op het aantal werkenden in 2002 volgens de EBB. De aggregatie over dezelfde beroepssegmenten binnen de verschillende bedrijfssectoren resulteert in de prognoses van de uitbreidingsvraag per beroepssegment.

Vervolgens zijn de prognoses per beroepssegment verbijzonderd naar beroepsgroepen. Hierbij is gebruik gemaakt van het random-coëfficiënten-model. De werkgelegenheidsgroei per beroepsgroep wordt daarbij geschat als afwijking van de totale groei van het beroepssegment waar de betreffende beroepsgroep onder valt. Om stabiele parameterschattingen te krijgen zonder daarbij de specificiteit van de afzonderlijke beroepen aan te tasten is gebruik gemaakt van een random-coëfficiënten-model. ${ }^{9}$ In dit random-coëfficiënten-model worden de parameterwaarden bepaald als een gewogen gemiddelde van aan de ene kant een gemiddelde parameterwaarde over de beroepsgroepen waarover gepoold wordt, en aan de andere kant schattingen voor de afzonderlijke beroepsgroepen. Het gewicht wordt bepaald door de nauwkeurigheid van beide onderdelen. Als er veel variatie is tussen de verschillende beroepsgroepen binnen een beroepssegment is een gepoolde schatting relatief onnauwkeurig en komt er meer gewicht op de afzonderlijke schattingen te liggen. Als deze afzonderlijke schattingen echter een hoge standaardfout hebben wordt hun gewicht verlaagd. Op deze wijze ontstaat er een optimale combinatie van de informatie van de gepoolde gegevens en de afzonderlijke schattingen.

9. Borghans en Heijke (1994) geven een uitvoerige beschrijving van dit model. 
$\Delta l_{t}^{g}=\Delta l_{t}^{j}+\beta_{0}^{g}+\beta_{I}^{g}\left(\Delta l_{t-1}^{g}-\Delta l_{t-1}^{j}\right)+\varepsilon_{t}$

waarbij:

$l_{t}^{g}=$ logaritme van het aantal werkzame personen in beroepsgroep $g$ op tijdstip $t$;

$l_{t}^{j}=$ logaritme van het totaal aantal werkzame personen in beroepssegment $j$ waartoe beroepsgroep $g$ wordt gerekend op tijdstip $t$.

Overigens is bij de schattingen van dit model een dummy-variabele voor 1992 en 1996 opgenomen. In de periode 1992-1995 heeft het CBS niet het beroep gecodeerd van mensen die een aanstelling hadden van minder dan een half jaar zonder vooruitzicht op verlenging. Omdat dit tot 1992 wel gebeurde en vanaf 1996 ook weer neemt het aantal mensen van wie het beroep niet gecodeerd is van 1991 op 1992 sterk toe en van 1995 op 1996 weer sterk af. Deze breuk in de data wordt opgevangen door een dummyvariabele voor 1992 en 1996 aan vergelijking (4.2) toe te voegen. Daarbij is verondersteld dat voor elke beroepsgroep in een bedrijfssector de proportionele afname van 1991 op 1992 als gevolg van niet coderen gelijk is aan de proportionele toename in 1996.

\section{Het opleidingenmodel}

Bij de prognoses die in 1993 werden opgesteld is voor het eerst expliciet een onderscheid gemaakt tussen de 'vraag' en de 'werkgelegenheid' per opleidingstype. Onder vraag wordt verstaan de hoeveelheid werk die wordt aangeboden als de verhoudingen op de arbeidsmarkt zich niet zouden wijzigen. Als er echter voor een bepaalde opleidingsrichting discrepanties ontstaan tussen de vraag- en aanbodontwikkeling, zullen er in de praktijk veelal aanpassingsprocessen ontstaan. Zo leidt een overschot aan de aanbodkant er mogelijk toe dat schoolverlaters banen krijgen waarin ze voorheen niet werkzaam waren. De uiteindelijke hoeveelheid werk wordt aangeduid als werkgelegenheid. Er ontstaat derhalve een verschil tussen het ex ante vraagbegrip en de ex post werkgelegenheid.

Om de te verwachten spanning tussen vraag en aanbod in kaart te brengen is de ex ante vraag het meest geschikt. De aanpassingen die achteraf plaatsvinden zijn immers al een uiting van deze spanningen tussen vraag en aanbod. In de data wordt echter de ex post vraag waargenomen. Door in het opleidingenmodel de historische vraag te baseren op deze feitelijke werkgelegenheid worden mogelijk vraag- en aanbodelementen samengenomen. Wanneer in het verleden een toename in de werkgelegenheid het gevolg was van een vergroot aanbod kan dit geïnterpreteerd worden als een toename van de ex ante vraag, waardoor de spanning tussen vraag en aanbod onderschat zal worden. Om deze verwarring tussen vraag- en aanbodelementen te voorkomen is door Borghans en Heijke (1996) een model ontwikkeld waarin het onderscheid tussen ex ante en ex post vraag naar arbeid expliciet is opgenomen. In dit model wordt, om deze twee afzonderlijke categorieën te kunnen identificeren, rekening gehouden met de onderlinge substitutie tussen opleidingstypen. In Borghans (1996) is dit model verder uitgewerkt. 
In figuur 4.2 wordt de opbouw van het model getoond. De ex ante vraag per opleidingstype (o) per beroepssegment $b$ wordt bepaald door de verdeling van de opleidingstypen in dit beroepssegment in het laatste observatiejaar. Op basis van het model van Borghans (1996) wordt geschat in welke mate de vraag naar een bepaald opleidingstype toe- of afneemt als gevolg van trendmatige verschuivingen. Deze veranderingen in de vraag weerspiegelen upen downgradingsprocessen in de werkgelegenheidsstructuur. Voor de prognoses van de werkgelegenheid naar opleiding zouden wegingsproblemen met de EBB-data voor 1998 een probleem kunnen betekenen. Daarom zijn deze voor de ontwikkelingen van de werkgelegenheidsstructuur naar opleiding niet gebruikt. In plaats daarvan zijn de schattingen van Borghans (1996) van trendmatige verschuivingen in de opleidingsstructuur gebruikt, waardoor de actuele economische ontwikkelingen alsnog kunnen worden gebruikt bij het maken van prognoses, zonder gebruik te maken van de EBB 1998.

Figuur 4.2

De opbouw van de vraag naar arbeid per opleidingstype

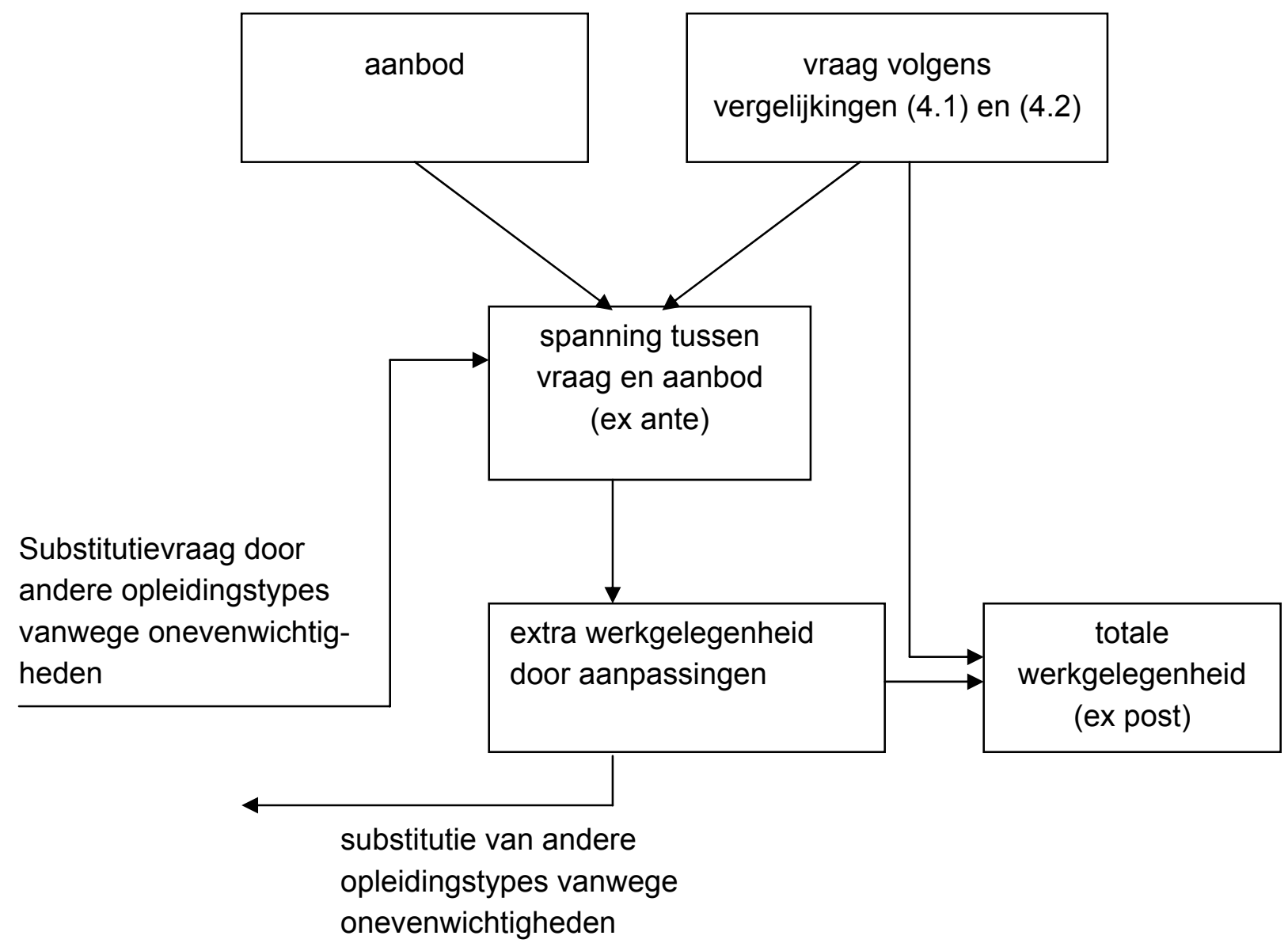

Ten slotte worden deze trendmatige ontwikkelingen gecorrigeerd voor een toe- of afname in de werkgelegenheid die het gevolg is van 'overschotten' of 'tekorten' aan mensen met een bepaalde opleidingsachtergrond. Als de vraag groter is dan het aanbod voor een bepaald opleidingstype zal immers de uiteindelijke werkgelegenheid zoals die wordt waargenomen kleiner zijn dan de oorspronkelijke vraag. Omgekeerd zal bij een aanbodoverschot de uiteindelijke werkgelegenheid juist groter worden vanwege verdringingsprocessen. Borghans 
en Willems (1998) gaan in op deze relatie tussen vraag en werkgelegenheid. Als het aanbod van een opleidingstype groter is dan de vraag, zal volgens dit model de arbeidsmarktpositie van het opleidingstype verslechteren. De nieuwkomers op de arbeidsmarkt zullen daardoor moeten uitwijken naar andere minder aantrekkelijke banen. Deze uitwijk naar andere banen is geschat op basis van de methode in Borghans (1996). Omdat de totale vraag per beroepssegment verondersteld wordt constant te zijn, betekent de instroom van het ene opleidingstype automatisch de verdringing van andere opleidingstypen. Hier wordt verondersteld dat deze uitstroom proportioneel is aan de opleidingsstructuur van dit beroepssegment. Deze verdringing betekent voor de betreffende opleidingstypes echter een vergroting van de discrepantie tussen vraag en aanbod. Door enkele malen een iteratie uit te voeren wordt een evenwichtssituatie gevonden die de ex ante vraag met substitutie aangeeft.

Deze uitbreidingsvraag met substitutie geeft aan hoe groot de vraag naar schoolverlaters met een bepaalde opleidingsachtergrond is, als er geen rekening wordt gehouden met de mate waarin dit opleidingstype zich aanpast aan de arbeidsmarktsituatie (de 'actieve substitutie'), maar waarbij wel rekening is gehouden met de vraagtoename, als gevolg van een vraagoverschot bij een andere verwante opleiding, of een vraagafname vanwege de verdringing door andere opleidingstypen (de 'passieve substitutie'). De reden waarom er geen rekening wordt gehouden met de 'actieve' substitutie is dat deze aanpassingen - in het geval van een aanbodoverschot - op zichzelf reeds een verslechtering zullen betekenen. Door de werkgelegenheid die door het aanpassingsproces op de arbeidsmarkt wordt verkregen in mindering te brengen op het aanbodoverschot zou een verslechterend perspectief onderschat worden. Het verlies aan werkgelegenheid door de aanpassingen van andere opleidingstypen betekent echter een verslechtering van de werkgelegenheid, zodat deze component wel moet worden meegenomen in de ex ante vraag (zie De Grip, Borghans en Smits, 1998).

Ook bij het opleidingenmodel hebben enkele aanpassingen van het basismodel plaatsgevonden. Bij de hogere onderwijskundige beroepen, de middelbare en hogere medische en paramedische beroepen en de hogere theologische beroepen is uitgesloten dat er substitutie plaatsvindt, omdat er in de praktijk scherpe afgrenzingen zijn tussen de vakgebieden van de beroepsgroepen die binnen deze beroepssegmenten worden onderscheiden.

\subsection{Methodiek vervangingsvraag}

Naast de uitbreidingsvraag is ook de vervangingsvraag een belangrijke component van het totaal aantal baanopeningen voor de nieuwkomers op de arbeidsmarkt. Met de vervangingsvraag wordt de vraag naar nieuwkomers bedoeld die ontstaat als gevolg van het verloop vanwege pensionering, VUT, arbeidsongeschiktheid, (tijdelijke) uittreding van met name gehuwde vrouwen, beroepsmobiliteit e.d. (zie ook Willems en De Grip, 1993). Bij een toename van de werkgelegenheid is de vervangingsvraag gelijk aan het aantal werkenden dat hun baan in een bepaalde periode verlaat. De opengevallen arbeidsplaatsen zullen 
immers eerst moeten worden opgevuld voordat er sprake kan zijn van werkgelegenheidsgroei. Echter, ook bij een dalende werkgelegenheid kan de vraag naar nieuwkomers, uitsluitend als gevolg van de vervangingsvraag, nog aanzienlijk zijn. Het blijkt dat werkgevers voor het realiseren van een afname van het personeelsbestand bij een teruglopende vraag naar arbeid aan de 'exit'-optie van ouderen de voorkeur geven boven de 'no entry'-optie van bijvoorbeeld schoolverlaters (zie Willems, Borghans en De Grip, 1997). De vervangingsvraag is dan echter niet gelijk aan de uitstroom, maar alleen aan de uitstroom voor zover deze vervangen wordt. Dit impliceert dat bij een krimpende vraag de vervangingsvraag lager zal zijn dan de uitstroom van werkenden.

Overigens dient te worden beseft dat de vervangingsvraag gesommeerd over alle beroepsgroepen niet gelijk is aan de vervangingsvraag gesommeerd over alle opleidingstypen. De beroepsmobiliteit is namelijk wel van invloed op de vervangingsvraag per beroepsgroep, maar heeft geen effect op de vervangingsvraag per opleidingstype. Het veranderen van beroep heeft immers geen gevolgen voor de opleidingsstructuur van de werkgelegenheid. Daarentegen kan een werkende door het afronden van een vervolgopleiding in feite 'uitstromen' naar een ander opleidingstype. In dat geval is er sprake van een vervangingsvraag bij het opleidingstype waartoe de vooropleiding van deze werkende wordt gerekend.

Voor het bepalen van de vervangingsvraag is een model ontwikkeld dat nauw aansluit bij de in demografische analyses vaker gebruikte cohort componenten methode. De cohortcomponenten-methode baseert de berekening van de zogenaamde 'cohort change rates' op het aantal personen in hetzelfde geboortecohort die werkzaam zijn in twee verschillende tijdsperioden. Een cohort is hier een combinatie van geslacht en vijfjaars-leeftijdsklasse. ${ }^{10}$ Deze methode maakt gebruik van standcijfers over de geslachts- en leeftijdsopbouw van de beroepsbeoefenaren over een aantal jaren. ${ }^{11}$ Door van jaar op jaar een vergelijking te maken van de demografische opbouw in een bepaalde beroepsgroep of een bepaald opleidingstype, wordt een beeld verkregen van de (netto) in- of uitstroom voor de desbetreffende beroepsgroep of het desbetreffende opleidingstype. Op dit model zal hier kort worden ingegaan (zie voor een verdere toelichting Willems, 1999).

Kernpunt bij de methodiek voor de bepaling van de vervangingsvraag is de afleiding van de netto in- en uitstroomratio's. Deze ratio's weerspiegelen de relatieve toe- of afname van het aantal werkenden in een beroepsgroep ${ }^{12}$ van een bepaald geboortecohort gedurende een bepaalde periode. In symbolen kunnen de 'cohort change rates' worden weergegeven als: ${ }^{13}$

10. Zie voor een verdere toelichting Shryock en Siegel (1980).

11. Bij het opstellen van de prognoses voor de periode 2003-2008 is gebruik gemaakt van naar geslacht en leeftijdsklasse verbijzonderde gegevens over het aantal werkenden per beroepsgroep en opleidingstype voor de periode 1987-2002, respectievelijk 1992-2002.

12. De methodiek is hier uitgewerkt voor de vervangingsvraag per beroepsgroep. De vervangingsvraag per opleidingstype wordt op vrijwel analoge wijze bepaald.

13. Daarnaast zijn de ratio's verbijzonderd naar geslacht. Omwille van de overzichtelijkheid van de notatie is de geslachtsindex weggelaten. 
$\dot{F}_{b x}^{t-1}=\frac{W_{b x+1}^{t}-W_{b x}^{t-1}}{W_{b x}^{t-1}}$

waarbij:

$\dot{F}_{b x}^{t-1}=$ netto in- of uitstroomratio van de werkenden in beroep $b$ met leeftijdklasse $x$ op tijdstip $t-1$, gedurende de periode $(t-1, t)$;

$W_{b x}^{t}=$ aantal werkenden in beroep $b$ in leeftijdsklasse $x$ op tijdstip $t$.

Indien $\dot{F}_{b x}^{t-1}>0$ dan is er sprake van netto instroom voor leeftijdscohort $x$ van beroep $b$ en als $\dot{F}_{b x}^{t-1}<0$ dan is er sprake van netto uitstroom. Er wordt dus met behulp van de cohort change rate de netto uitstroom, het saldo van uit- en instroom, in het verleden per beroepsgroep bepaald. De vervangingsvraag die wordt opgevuld door (her-)intredende personen van hetzelfde cohort (combinatie van geslacht én leeftijdsklasse) kan niet uit de beschikbare data worden afgeleid en wordt derhalve ook niet expliciet bij de bepaling van de vervangingsvraag meegenomen. Dit houdt in dat wordt aangenomen dat een meer dan normaal (op basis van het verleden) geacht aantal herintreders in de wachtrij voor nieuwe banen achteraan moet sluiten bij de nieuw op de markt komende schoolverlaters (zie ook Borghans, De Grip en Willems, 1995).

Vervolgens wordt er gebruik gemaakt van een random-coëfficiënten-model, waarbij de netto in- of uitstroomratio's worden verklaard op basis van enerzijds de gemiddelde in- of uitstroompatronen uit de totale werkzame bevolking en anderzijds de beroepsspecifieke afwijkingen per geslacht en leeftijdsklasse. Dit houdt in dat wanneer een geschatte uitstroomcoëfficiënt voor een bepaalde beroepsklasse of opleidingstype te sterk afwijkt, deze wordt vervangen door een meer robuuste uitkomst van een bovenliggende beroepsklasse of opleidingscategorie. Een dergelijke aanpak garandeert dat de som van de netto stromen over de beroepen overeenkomt met de totale netto in- of uitstroom.

In formulevorm:

$\dot{F}_{b}=\dot{F}+\sum_{x} \beta_{b x} D_{x}$

Waarbij:

$\dot{F}_{b}=$ vector van netto in- of uitstroomratio's voor beroep $b$, met waarnemingen per geslacht, leeftijdsklasse en jaar;

$\dot{F}=$ idem, maar dan voor de gehele werkzame bevolking;

$D_{x}=$ matrix met dummy-variabelen; waarden zijn gelijk aan 1 voor cohort $x$ en 0 elders; 
$\beta_{b x}=$ random parameters.

Vergelijking (4.4) laat zien dat de stromen van de arbeidsmarkt voor een bepaalde beroepsgroep per leeftijdscohort gelijk zijn aan de gemiddelde stroom van de arbeidsmarkt van dat leeftijdscohort, afgezien van beroepsspecifieke afwijkingen die kunnen verschillen per leeftijdsklasse. Onder de veronderstelling dat de niet-werkzame beroepsbevolking in de prognoseperiode gelijk blijft, kan met behulp van de door het CPB opgestelde prognoses van de participatiegraad, samen met de bevolkingsprognoses van het $\mathrm{CBS}$, een voorspelling worden gekregen van de toekomstige uitstroom uit de werkzame bevolking $(\dot{F})$. Daarmee wordt met behulp van vergelijking (4.4) tevens een prognose verkregen van de toekomstige netto in- en uitstroomratio's. Deze uitstroomcoëfficiënten worden vervolgens geprojecteerd op de populatie in het basisjaar ${ }^{14}$ om een prognose te kunnen maken van de uitstroom in de komende jaren. Deze prognose wordt gecorrigeerd voor de verwachte verandering in de arbeidsparticipatie per cohort voor de gehele beroepsbevolking. Naast deze participatiecorrectie vindt ook een vergelijkbare correctie plaats voor de conjuncturele situatie in de analyseperiode. Beide correctiefactoren zijn voor alle beroepsklassen en opleidingstypen gelijk.

De correctie voor de conjuncturele situatie is gelijk aan het verschil tussen de verandering in het totale aantal werkende personen en de verandering in de beroepsbevolking in de historische periode. Deze correctie compenseert de uitstroom van werkenden die werkloos zijn geraakt door conjuncturele fluctuaties in het werkgelegenheidsniveau. De correctie voor de verandering in de participatiegraad is het verschil tussen de groei in de beroepsbevolking in de historische periode en de voorspelperiode.

Als de correcties voor de conjunctuur en de participatiegraad gecombineerd worden dan levert dit de voorspelde toekomstige uitstroomratio per cohort op:

$$
\begin{aligned}
\dot{W}_{b x}^{t, m} & =\dot{W}_{b x}^{t, n}-\dot{W} P_{x}^{t, n}+\dot{L} F_{x}^{t, n}+\dot{L} F_{x}^{t, m}-\dot{L} F_{x}^{t, n} \\
& =\dot{W}_{b x}^{t, n}-\dot{W} P_{x}^{t, n}+\dot{L} F_{x}^{t, m}
\end{aligned}
$$

waarbij

$\dot{W}_{b x}^{t, m}=$ de verwachte gemiddelde jaarlijkse netto in- of uitstroomratio van werkenden in beroep $b$, in cohort $x$ op tijdstip $t$ gedurende de voorspelperiode $(t, t+m)$;

$\dot{W}_{b x}^{t, n}=$ de verwachte gemiddelde jaarlijkse netto in- of uitstroomratio van werkenden in beroep $b$, in cohort $x$ op tijdstip $t-n$ gedurende de periode $(t-n, t)$;

$\dot{W} P_{x}^{t, n}=$ de gemiddelde jaarlijkse groeiratio van het totale aantal werkende personen in cohort $x$ op tijdstip $t$ - $n$ gedurende de periode $(t-n, t)$;

14. Vanwege de kleine aantallen per leeftijdscohort waarop de bewerkingen zijn uitgevoerd, heeft aanvullend onderzoek inmiddels uitgewezen dat het hierbij zinvol te om over twee of drie jaren te middelen. 
$\dot{L} F_{x}^{t, n}=$ de gemiddelde jaarlijkse groeiratio van de beroepsbevolking in cohort $x$ op tijdstip $t$ $n$ gedurende de periode $(t-n, t)$;

$\dot{L} F_{x}^{t, m}=$ de verwachte gemiddelde jaarlijkse groeiratio van de beroepsbevolking in cohort $x$ op tijdstip t gedurende de voorspelperiode $(t, t+m)$.

Figuur 4.3

Samenvattend overzicht van de methodiek van de vervangingsvraag (excl. specifieke aanpassingen en 'doorleerderscomponent')

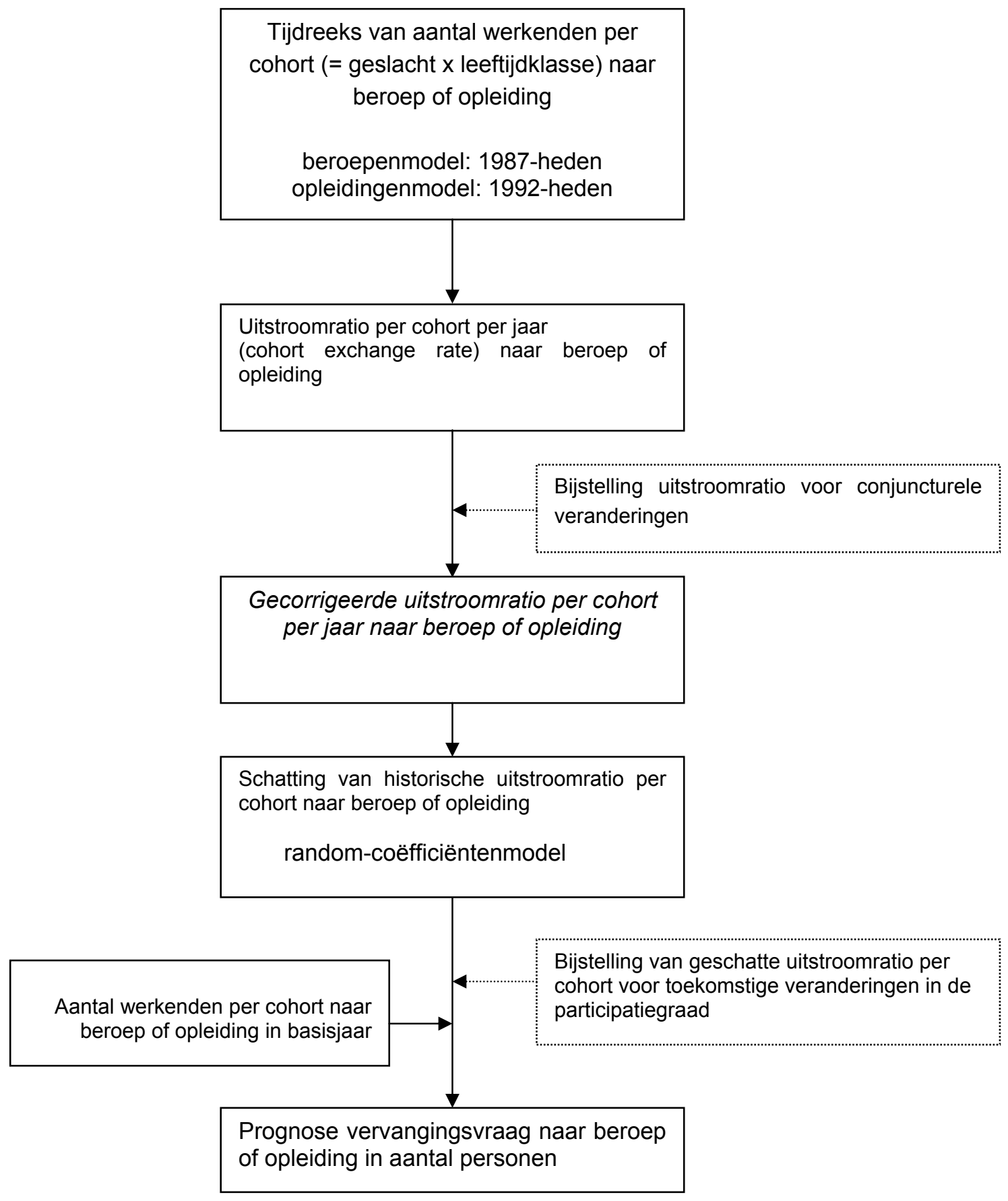


De toekomstige vervangingsvraag wordt vervolgens op dezelfde manier bepaald als de vervangingsvraag in de historische periode. Dit houdt in dat voor beroepsgroepen met een verwachte stijging van de werkgelegenheid de vervangingsvraag gelijk is aan de netto uitstroom. De ontwikkeling van de werkgelegenheid per beroepsgroep wordt per geslacht afzonderlijk bekeken. Voor beroepsgroepen waarbij een daling van de werkgelegenheid in een bepaald jaar voor één van beide geslachten wordt verwacht, wordt de vervangingsvraag voor het betreffende jaar en geslacht op nul gesteld. Figuur 4.3 bevat een samenvattend overzicht van de methodiek van het opstellen van de prognoses voor de vervangingsvraag. ${ }^{15}$

\section{Vervangingsbehoefte vanwege 'doorleerders'}

Om de vervangingsbehoefte per opleidingstype te bepalen, is dit jaar naast de vervangingsbehoefte die uit het beschreven model volgt, een tweede component onderscheiden. Het gaat hier om de vervangingsbehoefte die voortvloeit uit het feit dat sommige werkenden vervolgopleidingen volgen en daarmee een vervangingsbehoefte creëren voor de banen met de opleidingskwalificatie die ze oorspronkelijk hadden. Deze zogenaamde 'doorleerders' zijn dus werkenden die van opleiding veranderen en daarmee impliciet een vervangingsvraag genereren bij hun herkomstopleiding.

Op dit punt moeten de prognoses van de instroom van schoolverlaters en de vervangingsvraag naar opleidingstype vanzelfsprekend goed op elkaar worden afgestemd. Een probleem dat zich hierbij voordoet is dat bij de leeftijdsgroepen 20-24 jaar, 25-29 jaar en 3034 jaar de verwachte vervangingsvraag vanwege de 'uitstroom' van doorlerenden naar een hoger opleidingstype op basis van de bovenstaande methodiek niet goed wordt gemeten, omdat er in deze leeftijdsgroepen nog een aanzienlijke instroom plaatsvindt, waartegen de uitstroomcijfers wegvallen. Daarom baseren we ons voor deze leeftijdsgroep liever op de EBB-cijfers van degenen die door het afronden van een post-initiële opleiding een andere opleidingsachtergrond krijgen. Deze doorleerders veranderen van opleiding en laten een vervangingsvraag achter bij hun herkomstopleiding. De cijfers van de doorleerders naar herkomst vormen een betere afspiegeling voor de (vervangings)vraag in de jonge leeftijdsgroepen, dan de feitelijke uitstroomcijfers.

De bovengenoemde aanpassing is doorgevoerd voor genoemde cohorten en voor alle opleidingen met uitzondering van de opleidingen VMBO verzorging, MBO dokters-, tandartsen dierenartsassistent, MBO secretarieel en HBO toerisme in het cohort 30-34 jaar. Voor deze opleidingen die gekenmerkt worden door een groot aantal vrouwelijke afgestudeerden, geven de doorleercijfers naar onze inschatting juist een onderschatting van de feitelijke uitstroom (en daarmee de resulterende vervangingsvraag) te zien. Een tweede aanpassing van de vervangingsvraagprognose-methodiek is dat voor de opleidingen met een netto instroom in het cohort 30-34 jaar, de vervangingsvraag wordt verhoogd met de doorlerenden in deze leeftijdsgroep.

15. Zie Shah en Burke (2001) voor een vergelijking van de methodiek van de vervangingsvraag naar beroep tussen Australië, de Verenigde Staten en Nederland. 


\subsection{Methodiek instroom van schoolverlaters op de arbeidsmarkt}

De prognoses van de instroom op de arbeidsmarkt zijn gebaseerd op een verdeelmodel, dat een stapsgewijze modulaire opbouw heeft. Figuur 4.4 geeft een schematisch overzicht van deze opbouw. In het prognosemodel worden globaal gesproken twee stappen onderscheiden. In de eerste stap wordt de prognose opgesteld van de verwachte toekomstige uitstroom uit het regulier voltijdonderwijs. Niet voor alle schoolverlaters eindigt na het verlaten van het regulier voltijdonderwijs echter de schoolloopbaan. Na het verlaten van het voltijdonderwijs kan men immers nog doorstromen naar de beroepsbegeleidende leerweg, het overige deeltijdonderwijs, en het niet-reguliere voltijdonderwijs (incl. de beroepsgerichte volwasseneneducatie). Als men daar een diploma behaald heeft en de gevolgde opleiding heeft een hoger niveau of een andere opleidingsrichting dan de genoten vooropleiding, dan moet de instroomprognose worden bijgesteld. Deze bijstelling vindt plaats in stap twee.

\section{Stap 1}

Figuur 4.5 geeft een overzicht van de opzet van stap 1 van het prognosemodel. De gebruikte databronnen zijn weergegeven in de grijsgetinte vakken. Uitgangspunt bij de bepaling van de verwachte toekomstige instroom van schoolverlaters op de arbeidsmarkt is de beleidsarme variant van de Referentieraming van het Ministerie van Onderwijs, Cultuur en Wetenschappen (2003). Uit de Referentieraming worden de prognoses van het aantal schoolverlaters naar schoolsoort en -richting voor het regulier voltijdonderwijs gebruikt. Hierbij is in de Referentieraming een onderscheid gemaakt tussen de schoolverlaters met diploma en de schoolverlaters zonder diploma. Degenen die het regulier voltijdonderwijs zonder diploma verlaten, kunnen eerder een opleiding met diploma hebben afgesloten. De ongediplomeerde schoolverlaters worden daarom toegewezen aan hun eerdere hoogst voltooide vooropleiding in het voltijdonderwijs. Deze hoogst voltooide voltijdopleiding wordt vastgesteld aan de hand van de Onderwijsmatrix 2000 van het CBS. Dit resulteert in het verwachte aantal gediplomeerde schoolverlaters per opleidingsniveau en -richting. ${ }^{16}$

De indeling van opleidingen op basis van de onderwijsmatrix heeft een hoger aggregatieniveau dan de indeling naar opleidingstypen die het ROA (2002) hanteert. Daarom vindt er een uitsplitsing plaats om de toekomstige uitstroom uit het regulier voltijdonderwijs naar de arbeidsmarkt per ROA-opleidingstype te bepalen. Deze verdeling wordt gemaakt met behulp van gegevens over het aantal gediplomeerden van elk opleidingstype binnen een schoolsoort, de CBS-werktabellen. ${ }^{17}$ In deze tabellen worden de gediplomeerden op twee aggregatieniveaus van opleidingen weergegeven. Op het hogere aggregatieniveau worden

16. Voor MBO-schoolverlaters is een opsplitsing naar richting niet mogelijk.

17. De gegevens hebben betrekking op de periode van de laatste vijf jaren waarover gegevens beschikbaar zijn. Op basis hiervan wordt een trend in het aantal gediplomeerden per opleiding berekend. De gegevens van de lagere en middelbare beroepsopleidingen zijn op basis van CFItellingen van het Ministerie van OCenW vastgesteld en worden aan de hand van CREBO-codes gekoppeld aan de SOI '78. Voor het Hoger Onderwijs zijn de cijfers vastgesteld op basis van tellingen van de Informatie Beheer Groep, en worden aan de hand van de CROHO-codes gekoppeld aan de SOI '78. 
de CBS-werktabellen aan de Referentieraming gekoppeld en op het lagere niveau wordt de procentuele verdeling van schoolverlaters over opleidingen berekend waarmee de gegevens uit de Referentieraming worden vermenigvuldigd.

Figuur 4.4

Globaal schema ter bepaling van de verwachte toekomstige instroom van schoolverlaters op de arbeidsmarkt naar ROA-opleidingstype

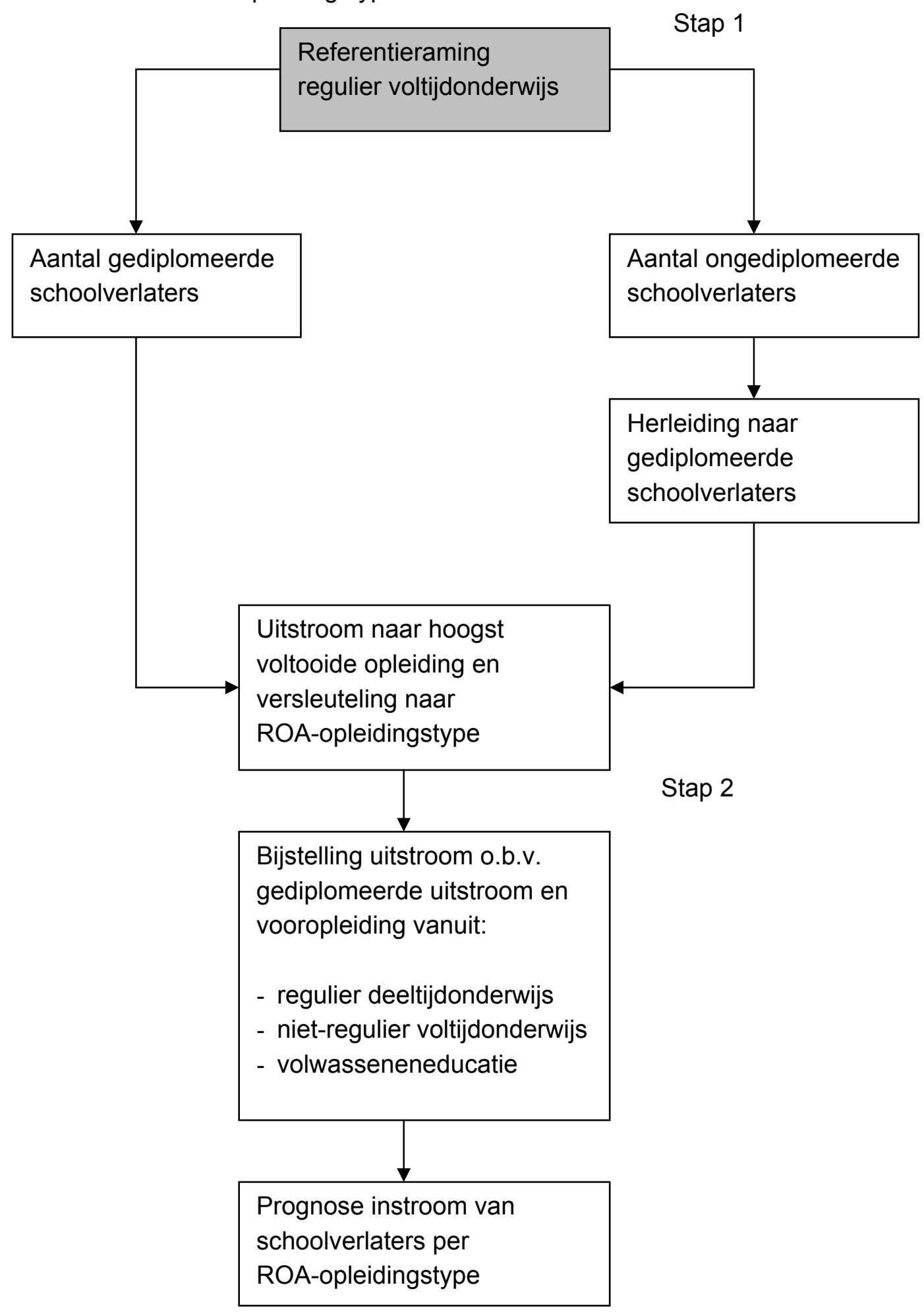


Figuur 4.5

Globaal overzicht van de eerste stap van de instroomprognoses van schoolverlaters van het regulier voltijdonderwijs op de arbeidsmarkt

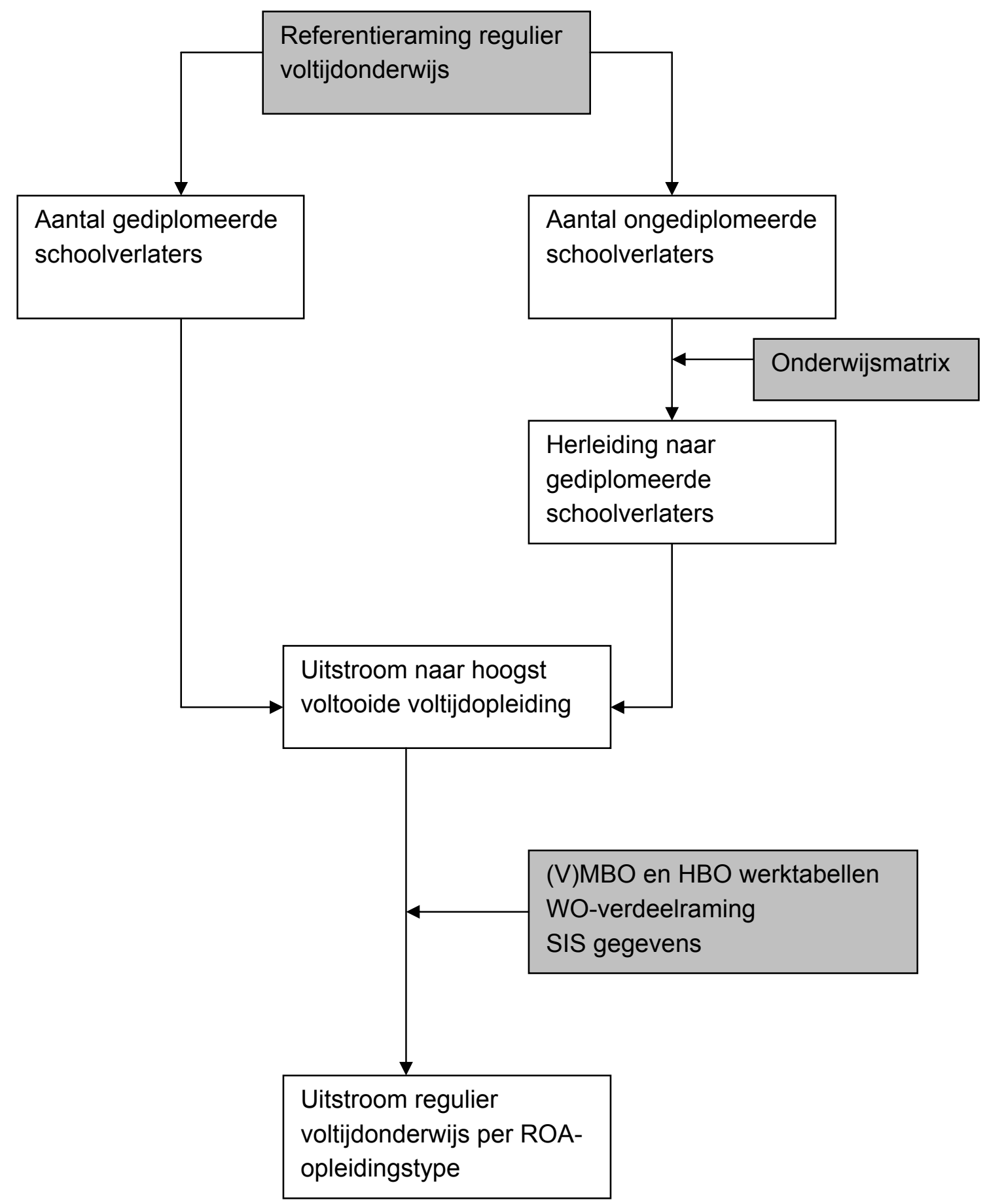

Voordat dit gebeurt, dient echter een correctie te worden uitgevoerd op de gegevens in de werktabellen. Omdat namelijk niet alle gediplomeerden schoolverlaters zijn, kan de verdeling van het aantal gediplomeerden afwijken van de verdeling van het aantal schoolverlaters. Op basis van de gegevens uit de RUBS-enquête, de HBO-Monitor en de WO-Monitor (kortweg SIS-gegevens) wordt het aandeel schoolverlaters binnen de groep gediplomeerden bepaald. 
Met deze gegevens wordt vervolgens de verdeling van de gediplomeerden over de opleidingsrichtingen binnen de schoolsoorten volgens de CBS-werktabellen bijgesteld. Vervolgens worden de gediplomeerde schoolverlaters aan de hand van de SOI-codes (zie ROA, 2002), behorende bij de opleidingen in de CBS-werktabellen, verdeeld over de verschillende opleidingstypen volgens de ROA-indeling. Tevens is voor de opleidingen in het wetenschappelijk onderwijs met een numerus fixus specifiekere informatie gebruikt. De WOverdeelraming 2000 geeft prognoses voor 73 WO-opleidingen. Deze kunnen aan de hand van de CROHO-codes aan de Standaard Onderwijsindeling (SOI '74) van het CBS en de ROA-opleidingstypen (zie ROA, 2002) gerelateerd worden.

Tot slot worden nog een laatste correctie uitgevoerd. Scholieren en studenten die na een bepaalde periode van afwezigheid terugkeren in het reguliere voltijd onderwijs, worden in de Referentieraming als schoolverlaters beschouwd, terwijl zij in feite doorstuderen. Aan de hand van gegevens van het CBS over de opleidingsachtergrond van deze groep, wordt er gecorrigeerd voor deze zogenaamde indirecte instroom in een opleiding (zie Cörvers en Golsteyn, 2003). Na stap 1 zijn de instroomprognoses voor schoolverlaters en afgestudeerden van het voltijdonderwijs gereed.

\section{Stap 2}

In stap 2 wordt, zoals reeds is aangegeven, de instroomprognose aangepast door rekening te houden met de doorstroom naar de beroepsbegeleidende leerweg (BBL, het voormalige leerlingwezen), het overige deeltijdonderwijs, en het niet-reguliere voltijdonderwijs (incl. de beroepsgerichte volwasseneneducatie). Bij de berekening van de instroomprognose in deze stap, kon in tegenstelling tot twee jaar geleden geen gebruik meer worden gemaakt van de Onderwijsrekeningen van het CBS, omdat deze niet meer samengesteld worden. Derhalve is de methodiek van stap 2 aangepast.

Het uitgangspunt voor de berekening van de instroom in stap 2 vormen de jaarbestanden 2000 t/m 2002 van de Enquête Beroepsbevolking van het CBS (zie bijv. CBS, 1999). Eerst worden op het 5-digit niveau van de Standaard Onderwijsindeling (SOI) de personen uit de EBB geselecteerd voor wie geldt dat het actuele onderwijs richting- en/of niveauveranderend is ten opzichte van het eerder hoogst behaalde onderwijs. Vervolgens wordt er op basis van de gegevens over de begindatum van de studie en de verwachte studieduur een schatting gemaakt wanneer de scholieren en studenten op de arbeidsmarkt instromen. Op dat moment wordt de actuele opleiding beschouwd als de hoogst behaalde opleiding en de eerder hoogst behaalde opleiding als vooropleiding.

Om een prognose te maken van het aantal schoolverlaters van de beroepsbegeleidende leerweg, wordt als randtotaal de prognose van de beroepsbegeleidende leerweg uit de Referentieraming 2003 genomen. Het randtotaal van de prognose van schoolverlaters van de beroepsbegeleidende leerweg wordt opgesplitst aan de hand van de prognoses van het aantal schoolverlaters per opleidingstype van het BBL. Zoals hierboven vermeld werden 
deze prognoses bepaald met gegevens over de begindatum van de studie en over de verwachte studieduur uit de EBB-bestanden van $2000 \mathrm{t} / \mathrm{m} \mathrm{2002.}{ }^{18}$

Voor het samenstellen van de prognoses van het aantal schoolverlaters dat uit het nietreguliere onderwijs op de arbeidsmarkt instroomt, is er ten opzichte van de prognoses voor de beroepsbegeleidende leerweg een aantal verschillen. In de eerste plaats zijn er geen randtotalen uit de Referentieraming beschikbaar voor deze schoolverlaters. Dit betekent dat de prognoses van het aantal schoolverlaters per opleidingstype die op grond van de gegevens uit de EBB zijn samengesteld, als absolute aantallen worden meegenomen in de instroomprognose. Ten tweede zijn er in het niet-reguliere onderwijs voltijd- en deeltijdschoolverlaters. Alle deeltijdschoolverlaters (die niet BBL volgden) worden tot het niet-reguliere onderwijs gerekend, en worden meegenomen in de instroomprognose volgens de hierboven vermelde methodiek. Voor de voltijdschoolverlaters zijn degenen met nietregulier onderwijs in de EBB niet te onderscheiden van degenen met het regulier onderwijs (zoals dit bij de beroepsbegeleidende leerweg wel mogelijk was). Dit is van belang omdat de schoolverlaters van het reguliere onderwijs al in stap 1 zijn meegenomen. Op grond van De Grip en Jacobs (1999) behoren schoolverlaters tot het reguliere voltijdonderwijs als de schoolverlater en de gevolgde opleiding van de schoolverlater aan de criteria in tabel 4.1 voldoen.

Tabel 4.1

Criteria waaraan moet worden voldaan om een opleiding als reguliere voltijdopleiding te definiëren

Opleidingsniveau Leeftijd bij diplomering Opleidingsduur

\begin{tabular}{lll}
\hline MAVO & $\leq 19$ jaar & \\
VBO & $\leq 20$ jaar & \\
HAVO & $\leq 19$ jaar & \\
VWO & $\leq 20$ jaar & $\geq 3$ jaar \\
MBO & $<24$ jaar & $\geq 3$ jaar \\
HBO & $\geq 21$ jaar en $<30$ jaar & $\geq 4$ jaar \\
WO & $\geq 22$ en $\leq 30$ jaar &
\end{tabular}

Bron: De Grip en Jacobs (1999)

Alleen schoolverlaters die buiten deze criteria vallen worden beschouwd als uitstroom uit het niet-reguliere onderwijs, en worden derhalve in stap 2 meegenomen als instroom op de arbeidsmarkt.

Tot slot is het van belang op te merken dat er degenen die niet-reguliere onderwijs volgen en met een dergelijke opleiding op de arbeidsmarkt komen, zowel reeds werkend kunnen zijn als niet-werkenden. Dit heeft consequenties voor de vervangingsvraag naar de vooropleiding van deze 'schoolverlaters'. Doordat de werkenden van opleidingsachtergrond veranderen ontstaat er, evenals bij de BBL'ers, vervangingsvraag naar hun vooropleiding.

18. De geprognosticeerde vooropleiding van de schoolverlaters uit het BBL (veelal een VMBOopleiding) wordt vervolgens als vervangingsvraag naar VMBO'ers beschouwd (zie paragraaf 4.3). 
Bij de niet-werkenden ontstaat er echter geen vervangingsvraag naar de vooropleiding, maar een lagere arbeidsmarktinstroom van de betreffende vooropleiding. Zij kunnen dus als scholieren of studenten die in het niet-reguliere onderwijs zijn gaan doorstuderen worden beschouwd. De arbeidsmarktinstroom dient derhalve voor de opleidingstypen waarop deze vooropleiding betrekking heeft naar beneden te worden bijgesteld.

$\mathrm{Na}$ de bijstelling van de instroom van het reguliere voltijdonderwijs met de instroom van het BBL en het niet-reguliere onderwijs in stap 2 resulteert de toekomstige instroom van schoolverlaters op de arbeidsmarkt per ROA-opleidingstype voor de prognoseperiode 20032008.

\subsection{Baanopeningen en typering arbeidsmarktperspectieven}

Voor de opleidingen kunnen de verwachte vraag naar nieuwkomers en het verwachte aanbod aan elkaar worden gerelateerd. De verwachte vraag is gelijk aan het aantal baanopeningen dat in de prognoseperiode ontstaat als gevolg van de uitbreidings- en vervangingsvraag. Voor zover nieuwkomers op de arbeidsmarkt hinder ondervinden van een krimpende werkgelegenheid, wordt dit met de vervangingsvraag verrekend (zie paragraaf 4.3). De vervangingsvraag wordt immers alleen beïnvloed door de uitstroom van werkenden voor zover dit tot nieuwe vraag leidt.

Voor nieuwkomers op de arbeidsmarkt is de uitstroom van werkenden van de arbeidsmarkt alleen relevant indien door het verloop nieuwe vacatures ontstaan. ${ }^{19}$ Omdat ook de uitbreidingsvraag een netto-grootheid is geldt per definitie dat in geval van een groeiende werkgelegenheid de vervangingsvraag gelijk is aan het verloop. Als de werkgelegenheid krimpt, zijn er meer uitstromers dan instromers. Dit verschil is ook per definitie gelijk aan de (negatieve) uitbreidingsvraag. Het verband tussen vervangingsvraag en uitstroom ligt dus, bij een gegeven uitbreidingsvraag, vast. Er geldt:

vervangingsvraag $=$ uitstroom $+\mathrm{MIN}\{$ uitbreidingsvraag, 0$\}$

Op basis van deze identiteit kan het aantal baanopeningen op twee manieren worden vastgesteld. Ten eerste kan men uitgaan van de uitstroom en deze salderen met de uitbreidingsvraag:

baanopeningen $=$ uitstroom + uitbreidingsvraag

De tweede mogelijkheid is uit te gaan van de vervangingsvraag en hierbij indien er sprake is van een groeiende werkgelegenheid, de uitbreidingsvraag op te tellen:

baanopeningen $=$ vervangingsvraag $+\operatorname{MAX}\{0$, uitbreidingsvraag $\}$

19. Op de relatie tussen vacatures enerzijds en baanopeningen anderzijds wordt nader ingegaan in De Grip, Meijboom en Willems (1995). 
Substitutie van de definitie van vervangingsvraag in de laatste vergelijking laat zien dat beide methodes gelijkwaardig zijn. De definitie op basis van de vervangingsvraag laat bovendien zien dat het aantal baanopeningen nooit negatief kan zijn. Naast het totaal aantal baanopeningen uit hoofde van uitbreidings- en vervangingsvraag wordt aan de vraagkant rekening gehouden met de substitutievraag (zie paragraaf 4.2).

Als aanbod op de arbeidsmarkt is de som genomen van de verwachte instroom in de periode 2003-2008 en het aantal werklozen aan het begin van de prognoseperiode dat korter dan 1 jaar werkloos is. Dit laatste is op te vatten als het boven de markt zwevende aanbod van werklozen aan het begin van de prognoseperiode. De bepaling van het aantal kortdurig werklozen is gebaseerd op het totaal aantal werklozen per opleidingstype volgens de EBB, vermenigvuldigd met het aandeel werklozen dat hooguit een jaar werkloos is. Dit aandeel is bepaald met behulp van gegevens van het Centrum voor Werk en Inkomen. ${ }^{20}$ Vervolgens wordt de Indicator Toekomstige Arbeidsmarktperspectieven (ITA) bepaald volgens de formule:

$$
I T A=\frac{(100+\text { instroom } \%+\text { kortdurig werklozen } \%)}{(100+\max \{0, \text { uitbreidingsvraag } \%\}+\text { vervangingsvraag } \%+\text { substitutievraag } \%)}
$$

Naarmate de waarde van de ITA hoger ligt, is er sprake van een slechter arbeidsmarktperspectief. Een waarde rond de 1 duidt op een evenwichtssituatie. Om te bewerkstelligen dat de grens tussen een goed en een redelijk perspectief precies bij 1 ligt en om discrepanties tussen de ITA en de typering te voorkomen, wordt de ITA naar boven afgerond (zie Wieling, De Grip en Willems, 1990).

\subsection{Typering knelpunten in de personeelsvoorziening}

\section{Knelpunten naar opleidingstype}

Naast de verwachte arbeidsmarktsituatie voor nieuwkomers is ook ingegaan op de verwachte knelpunten in de personeelsvoorziening. De indicator hiervoor is in principe het spiegelbeeld van de ITA. Als de vraag naar werkenden met een bepaalde opleidingsachtergrond groter is dan het aanbod kunnen knelpunten in de personeelsvoorziening verwacht worden. Vergelijkbaar met de Indicator Toekomstige Arbeidsmarktperspectieven (ITA) geeft de Indicator van de Toekomstige Knelpunten in de Personeelsvoorziening (ITKP) deze vraag-aanbodspanning aan. Bij een krimpende werkgelegenheid voor een bepaald opleidingstype wordt de totale vraag ('recruteringsbehoefte') echter op een enigszins andere

20. Met de EBB is het aandeel kortdurig werklozen niet goed te bepalen. De CWI-gegevens over nietwerkende werkzoekenden (NWW) laten echter geen betrouwbare differentiatie naar opleidingstype toe. Het aandeel kortdurig werklozen is met NWW-gegevens derhalve per opleidingsniveau bepaald. 
wijze berekend dan het aantal baanopeningen voor nieuwkomers op de arbeidsmarkt. Verschil met de ITA is dat bij de ITKP de uitstroom van werkenden als gevolg van een krimpende werkgelegenheid is meegerekend in de vraag, omdat verwacht mag worden dat bij knelpunten in de personeelsvoorziening deze (gedwongen) uitstroom kan worden afgeremd of elders werk zou kunnen vinden. Zeker wanneer bedrijven geconfronteerd worden met een krappe arbeidsmarkt voor een bepaald opleidingstype, zullen zij van deze mogelijkheid gebruik maken. Voor het overige is de Indicator Toekomstige Knelpunten in de Personeelsvoorziening (ITKP) gelijk aan de ITA. Naarmate de waarde van de indicator lager wordt, zijn de verwachte knelpunten in de personeelsvoorziening groter.

$$
I T K P=\frac{(100+\text { instroom } \%+\text { kortdurig werklozen } \%)}{(100+\text { uitbreidingsvraag } \%+\text { vervangingsvraag } \%+\text { substitutievraag } \%)}
$$

\section{Knelpunten naar beroepsgroep}

Voor het indiceren van de knelpunten in de personeelsvoorziening naar beroepsgroep kan niet een soortgelijke aanpak worden gevolgd, omdat het aanbod per beroepsgroep niet goed is vast te stellen. Daarom is een indicator ontwikkeld waarvoor geen voorspellingen van het arbeidsaanbod naar beroep nodig zijn.

De knelpunten in de personeelsvoorziening naar beroepsgroep nemen de prognoses van vraag en aanbod naar opleidingstype als uitgangspunt. Daarbij is als volgt te werk gegaan.

Het aanbod van een opleidingstype $i$ op tijdstip $t\left(\right.$ aanbod $\left._{i, t}\right)$ is gelijk aan het aanbod op tijdstip $t$-1 (het 'basisjaar' van de prognoseperiode) plus de arbeidsmarktinstroom van schoolverlaters in de periode tussen $t-1$ en $t$ minus de vervangingsvraag over dezelfde periode:

$$
\operatorname{aanbod}_{i, t}=x_{i, t-1}+w l h_{i, t-1}+\operatorname{nieuw}_{i}-v v_{i}
$$

waarbij:

$$
\begin{aligned}
& x_{i, t-1} \quad \text { het totaal aantal werkenden met opleiding } i \text { in } t-1 \text {; } \\
& w l h_{i, t-1} \quad \text { het aantal kortdurige werklozen met opleidingstype } i \text { in } t \text {-1; } \\
& \text { nieuw }_{i} \text { de arbeidsmarktinstroom van schoolverlaters met opleidingstype } i \text { voor de } \\
& \text { periode tussen } t \text { - } 1 \text { en } t \text {; } \\
& v v_{i} \quad \text { de vervangingsvraag voor opleidingstype } i \text { in over de periode tussen } t-1 \text { en } t \text {. }
\end{aligned}
$$

De kans om een werknemer aan te trekken met opleidingstype $i$ wordt gegeven door:

$$
p_{i}=\frac{\operatorname{aanbod}_{t, t}}{x_{i, t}} \quad \text { als } \text { aanbod }_{i, t} \leq x_{i, t}
$$


$p_{i}=1 \quad$ als aanbod $_{i, t}>x_{i, t}$

$x_{i, t}$ is de verwachte vraag naar opleiding $i$ op tijdstip $t$. We veronderstellen dus dat de kans om iemand met opleidingstype $i$ aan te trekken gelijk is voor alle beroepsgroepen. Dat betekent dat tekorten proportioneel over beroepen verdeeld zullen zijn.

De alternatieve indicator voor de toekomstige knelpunten in de personeelsvoorziening naar beroepsgroep $\left(I T K B_{j}\right)$ als gevolg van aanbodtekorten bij opleidingen waaruit de werkenden in beroep $j$ worden gerecruteerd, wordt dan gegeven door:

$$
I T K B_{j}=\frac{\sum_{i} p_{i} x_{i j, t}}{\sum_{i} x_{i j, t}} ; \quad 0 \leq I T K B_{j} \leq 1
$$

De $I T K B_{j}$ is een relatieve maatstaf voor knelpunten. De noemer geeft de totale vraag vanuit beroepsgroep $j$ en de teller de verwachte vervulling van deze vraag. De $I T K B_{j}$ geeft dus de mate waarin de vraag vanuit beroepsgroep $j$ in de gewenste samenstelling vervuld zal kunnen worden. Naarmate de waarde van $I T K B_{j}$ lager is, zijn er meer knelpunten te verwachten. Als $I T K B_{j}=1$ dan worden er geen knelpunten verwacht bij het vervullen van de vraag vanuit beroepsgroep $j$. Een $I T K B_{j}$ van 0 betekent derhalve dat de vraag vanuit beroep $j$ in het geheel niet vervuld kan worden.

Deze indicator heeft echter een nadeel. De indicator geeft aan in welke mate het mogelijk is om de gewenste personeelsamenstelling te bereiken maar houdt geen rekening met de mogelijkheid om tekorten bij een opleiding aan te vullen door mensen met een andere (aanverwante) opleiding te rekruteren. Met eventuele substitutieprocessen wordt dus geen rekening gehouden. Dit impliceert dat een eventuele vermindering van de knelpunten als gevolg van passief substitutie-aanbod vanuit andere opleidingen in deze alternatieve indicator niet tot uiting komen.

\section{De structurele arbeidsmarktsituatie}

\subsection{Inleiding}

Naast de informatie over de actuele arbeidsmarktsituatie en de prognoses voor de ontwikkelingen op de arbeidsmarkt voor de middellange termijn, verschaft het informatiesysteem onderwijs-arbeidsmarkt ook inzicht in de structurele arbeidsmarktpositie van beroepsgroepen en opleidingstypen. Deze indicatoren beogen de kracht of kwetsbaarheid van een bepaalde beroepsgroep of opleidingsachtergrond op de arbeidsmarkt aan te duiden, ongeacht de specifieke actuele situatie of de voorspelde ontwikkelingen in de vraag-aanbodverhoudingen. 
Het gaat hierbij om de indicator voor de conjunctuurgevoeligheid van de werkgelegenheid en de indicatoren voor de uitwijkmogelijkheden op de arbeidsmarkt. Daarnaast is ook gebruik gemaakt van een indicator voor de substitutiemogelijkheden die werkgevers hebben tussen arbeidskrachten met uiteenlopende opleidingsachtergronden en de concurrentie-index die aangeeft welke opleidingen een sterke verwantschap vertonen in hun beroependomein.

In dit hoofdstuk worden deze indicatoren besproken. Eerst wordt de indicator voor de conjunctuurgevoeligheid gesproken. In de daarop volgende paragraaf wordt ingegaan op de indicatoren van en de substitutiemogelijkheden op de arbeidsmarkt en de uitwijkmogelijkheden. In de laatste paragraaf wordt ingegaan op de concurrentie-index.

\subsection{Conjunctuurgevoeligheid}

De indicator voor de conjunctuurgevoeligheid geeft aan in welke mate de werkgelegenheid voor een bepaalde beroepsgroep of opleidingstype fluctueert als gevolg van schommelingen in de werkgelegenheid van bedrijfssectoren. De conjunctuurgevoeligheid van bedrijfssectoren wordt vastgesteld op grond van: ${ }^{21}$

$$
C I_{s}=100 \sum_{t} \frac{\left|w_{s}^{t}-\bar{w}_{s}^{t}\right|}{w^{t}}
$$

waarbij:

$C I_{s} \quad$ conjunctuurgevoeligheid van bedrijfssector $s$;

$w_{s}^{t} \quad$ de werkgelegenheid in bedrijfssector $s$ in jaar $i$;

$\bar{w}_{s}^{t} \quad$ de trend van de werkgelegenheid in bedrijfssector $s$ in jaar $t$.

De trend wordt berekend als:

$$
\bar{w}_{s}^{t}=\frac{w_{s}^{t-1}+w_{s}^{t+1}}{2}
$$

De indicator wordt vastgesteld op basis van gegevens van het totale arbeidsvolume uit de Nationale Rekeningen voor de periode 1977 tot 2002. ${ }^{22}$ In de praktijk blijken echter de productieberoepen sterker beïnvloed te worden door deze schommelingen dan andere functies. Om hiervoor te corrigeren wordt het verband vastgesteld tussen de werkgelegenheidsfluctuaties in een beroepssegment $\Delta W_{p s}^{t}$ en de schommelingen in een bedrijfssector:

$$
\Delta W_{p s}^{t}=C_{p s}+\alpha_{p s} \Delta W_{s}^{t}
$$

21. De conjunctuurindicator wordt hierbij genormeerd naar de waarde 1.

22. Zie CBS $(1995,1996)$ voor de oudere tijdreeksen. 
Dit verband is geschat op basis van de EBB van 1996 tot 2002. $\alpha_{p s}$ geeft aan in welke mate de werkgelegenheid in een bepaald beroepssegment meefluctueert met de werkgelegenheid van de bedrijfssector. De conjunctuurgevoeligheid van een beroepsgroep $b$ is vastgesteld als: ${ }^{23}$

$$
C I_{b}=\sum_{s} \frac{W_{b s}^{2002}}{W_{s}^{2002}} \alpha_{p s} C I_{s}
$$

Hierbij is $p$ het beroepssegment dat beroepsgroep $b$ omvat. Omdat bij een aantal beroepen waarbij het aandeel in de werkgelegenheid in een bedrijfssector vrij klein is, de schattingen van $\alpha_{p s}$ vrij extreme waarden aannamen, is de randvoorwaarde gesteld dat $\alpha_{p s}$ tussen 0,3 en 3,0 moet liggen.

Omdat de werkgelegenheid van mensen met een bepaalde opleidingsachtergrond deels ook aanbodbepaald is, is een soortgelijke aanpak voor de berekening van de conjunctuurgevoeligheid van opleidingstypen niet zinvol. Om die reden is bij het bepalen van de conjunctuurgevoeligheid van een bepaald opleidingstype het gewogen gemiddelde genomen van de beroepsgroepen waarin degenen uit deze opleidingsachtergrond werkzaam zijn.

$$
C I_{O}=\sum_{b} \frac{W_{o b}^{2002}}{W_{b}^{2002}} C I_{b}
$$

\subsection{Uitwijk- en substitutiemogelijkheden}

Omdat er in het algemeen geen één-op-één-relatie bestaat tussen opleiding en beroep of tussen opleiding en bedrijfssector is het zinvol om aan te geven hoe breed het domein is waarin mensen met een bepaalde opleidingsachtergrond werk vinden. De maatstaf die hiervoor wordt gebruikt is de Gini-Hirschman-index. De spreiding van een opleidingstype over beroepsgroepen wordt aangegeven door:

$$
G H_{o}^{b e r}=\frac{1}{\sum_{b}\left(\frac{W_{o, b}}{W_{o}}\right)^{2}}
$$

Deze maatstaf kan geïnterpreteerd worden als het gestandaardiseerde aantal beroepen waarin men terecht komt. Bij een volledige concentratie van de werkgelegenheid in één beroepsgroep is de indicator gelijk aan 1 . Bij een gelijke spreiding over $n$ beroepsgroepen is de indicator gelijk aan $n$. Bij een ongelijke spreiding tellen beroepsgroepen met een relatief laag werkgelegenheidsaandeel minder zwaar mee dan beroepsgroepen met een groot

23. Ook hier wordt de conjunctuurindicator wordt hierbij genormeerd naar de waarde 1. 
werkgelegenheidsaandeel. Op vergelijkbare wijze kunnen de uitwijkmogelijkheden van een opleidingstype of een beroepsgroep naar bedrijfssectoren worden vastgesteld.

Daarnaast wordt een indicatie gegeven van de substitutiemogelijkheden die een werkgever heeft in de selectie van mensen met een uiteenlopende opleidingsachtergrond. Daarbij is de spreiding van de werkgelegenheid in een beroepsgroep over de opleidingstypen als volgt vastgesteld:

$$
G H_{b}^{\text {subs }}=\frac{1}{\sum_{o}\left(\frac{W_{o, b}}{W_{b}}\right)^{2}}
$$

\subsection{Concurrentie-index}

Naast het feit dat een opleidingstype tot werk in meerdere beroepen kan leiden, kan er tussen de werkgelegenheid van opleidingstypen ook een overlap bestaan. De concurrentieindex die hiervoor wordt gebruikt (zie Borghans, 1992) is afgeleid van de Gini-Hirschmanindex en luidt als volgt:

$$
S_{o, o o}=\frac{\sum_{b}\left(\frac{W_{o, b}}{W_{o}}\right)\left(\frac{W_{o o, b}}{W_{o o}}\right)}{\sqrt{\sum_{b}\left(\frac{W_{o, b}}{W_{o}}\right)^{2} \sum_{b}\left(\frac{w_{o o, b}}{W_{o o}}\right)^{2}}}
$$

Deze index geeft aan hoe groot de kans is dat personen met een verschillende opleidingsachtergrond (respectievelijk $o$ en $o o$ ) in dezelfde beroepsgroep werkzaam zijn. Omdat bij opleidingstypen met een grote beroepenspreiding deze kans a priori reeds klein is, is deze voor beroepenspreiding gecorrigeerd.

\section{Literatuur}

Borghans L. (1992), A Histo-Topographic Map of the Dutch University Studies, ROA-W-1992/5E, Universiteit Maastricht.

Borghans, L. (1996), Effects of supply and demand on the employment structure, mimeo, Universiteit Maastricht.

Borghans, L., A. de Grip, H. Heijke (2000), Alice in prognoseland. Over de zin van arbeidsmarktprognoses, ROA-W-2000/6, Universiteit Maastricht.

Borghans, L., A. de Grip, E. Willems (1995), Herijking ROA-Informatiesysteem Onderwijs-Arbeidsmarkt, ROA-R-1995/1, Universiteit Maastricht.

Borghans, L., H. Heijke (1994), Een random-coëfficiënten-model voor het voorspellen van de beroepenstructuur van bedrijfstakken, ROA-W-1994/1, Universiteit Maastricht. 
Borghans, L., H. Heijke (1996), Forecasting the Educational Structure of Occupations: a Manpower Requirement Approach with Substitution, Labour, Vol. 10, pp. 151-192.

Borghans, L., E. Willems (1998), Interpreting Gaps in Manpower Forecasting Models, Labour, Vol. 12, pp. 663-641.

Centraal Bureau voor de Statistiek (1993), Standaard Beroepenclassificatie 1992, Sdu, Den Haag.

Centraal Bureau voor de Statistiek (1995), Nationale Rekeningen: gereviseerde reeksen 1977-1986, Voorburg/Heerlen.

Centraal Bureau voor de Statistiek (1996), Nationale Rekeningen: gereviseerde reeksen 1969-1976, Voorburg/Heerlen.

Centraal Bureau voor de Statistiek (1999), Enquête Beroepsbevolking 1998, Voorburg/Heerlen.

Centraal Planbureau (1990), ATHENA Een bedrijfstakkenmodel voor de Nederlandse economie, Werkdocument No. 30, Den Haag.

Centraal Planbureau (2003), Centraal Economisch Plan 2003, Den Haag.

Cörvers, F., B.J. Diephuis, S. Dijksman, B. Golsteyn, M. Hensen, Ph. Marey (2002), Methodiek arbeidsmarktprognoses en -indicatoren 2001-2006, ROA-W-2002/4, Universiteit Maastricht.

Cörvers, F., B. Golsteyn (2003), De invloed van voortijdige schooluitval op de instroomprognoses van schoolverlaters op de arbeidsmarkt, ROA-W-2003/1, Universiteit Maastricht.

Cörvers, F., A. de Grip, H. Heijke (2002), Beyond manpower planning: a labour market model for the Netherlands and its forecasts to 2006, in: M. Neugart and K. Schömann (eds), Forecasting Labour Markets in OECD countries, Edward Elgar, pp. 185-223.

Cörvers, F. (2003), Labour market forecasting in the Netherlands: a top-down approach, in: S.L. Schmidt, K. Schömann, M. Tessaring (eds.), Early identification of skill needs in Europe, Cedefop Reference Series, Vol. 40, Thessaloniki, pp. 72-83.

Dupuy, A., F. Cörvers (2003), A micro-economic foundation of modelling and forecasting the occupational structure of economic sectors, Paper presented at the conference 'Modelling labour market: Realities and prospects', Employment Observatory Research Informatics, Athens.

Eijs, P. van, A. de Grip (1998) De ontwikkeling van het project onderwijs-arbeidsmarkt 1986-1998, ROA-W-1998/7, Universiteit Maastricht.

Engle, R.F., C.W.J. Granger (1987), Co-integration and error correction: Representation, estimation, and testing, Econometrica, Vol. 55, pp. 251-276 .

Grip, A. de, L. Borghans, W. Smits (1998), Future Developments in the Job Level and Domain of High-skilled Workers, in: H. Heijke, L. Borghans (eds), Towards a Transparent Labour Market for Educational Decisions, Ashgate, Aldershot/Brookfield USA/Singapore/Sydney, 1998, pp. 21-56.

Grip, A. de, H. Heijke (1998), Beyond Manpower Planning: ROA's Labour Market Model and its Forecasts to 2002, ROA-W-1998/6E, Universiteit Maastricht.

Grip, A. de, A. Jacobs (1999), De doorstroom van het initieel onderwijs naar het niet-initieel onderwijs, ROA-W-1999/3, Universiteit Maastricht.

Grip, A. de, P. Meijboom, E. Willems (1995), Vacatures, werkgelegenheidsontwikkeling en de vraag naar nieuwkomers op de arbeidsmarkt, in: Tijdschrift voor Politieke Economie, vol. 18, pp. 36-57. 
Grip, A. de, R.K.W. van der Velden, M.H. Wieling (1991), Indicatoren aansluiting onderwijsarbeidsmarkt MDGO. Enkele arbeidsmarktindicatoren op basis van de RUBS-data, ROA-R1991/2, Universiteit Maastricht.

Heijke, H., A. Matheeuwsen, E. Willems (2003), Clustering Educational Categories in a Heterogeneous Labour Market, Education Economics, Vol. 11, pp. 89-108.

Ministerie van Onderwijs, Cultuur en Wetenschappen (2003), Referentieraming 2003, Zoetermeer.

Researchcentrum voor Onderwijs en Arbeidsmarkt (1999), De arbeidsmarkt naar opleiding en beroep 2004, ROA-R-1999/8 en 8B, Universiteit Maastricht.

Researchcentrum voor Onderwijs en Arbeidsmarkt (2001), De arbeidsmarkt naar opleiding en beroep 2006, ROA-R-2001/8, Universiteit Maastricht.

Researchcentrum voor Onderwijs en Arbeidsmarkt (2002), ROA-classificatiegids 2002, ROA-R2002/3, Universiteit Maastricht.

Researchcentrum voor Onderwijs en Arbeidsmarkt (2003), De arbeidsmarkt naar opleiding en beroep 2008, ROA-R-2003/11, Universiteit Maastricht.

Researchcentrum voor Onderwijs en Arbeidsmarkt (2003a), Schoolverlaters tussen onderwijs en arbeidsmarkt 2002, ROA-R-2003/9 en 9B, Universiteit Maastricht.

Shah, C., G. Burke (2001), Occupational Replacement Demand in Australia, International Journal of Manpower, Vol. 22, pp. 648-663.

Shyrock, H.S., J.S. Siegel (1980), The Methods and Materials of Demography, U.S. Bureau of the Census, U.S. Printing Office, Fourth Printing (rev.), Washington D.C.

Wieling M.H., A. de Grip, E.J.T.A. Willems (1990), Een systematische kwalitatieve typering van arbeidsmarktinformatie, ROA-W-1990/8, Universiteit Maastricht.

Willems, E. (1999), Modelling Replacement Demand: a Random Coefficient Approach, ROA-RM1999/2E, Universiteit Maastricht.

Willems, E., L. Borghans, A. de Grip (1997), Exit or no entry? Replacement demand and shrinking employment, ROA, Paper for the EALE conference, Aarhus, Denmark.

Willems, E.J.T.A., A. de Grip (1993), Forecasting Replacement Demand by Occupation and Education, International Journal of Forecasting, vol. 9, nr. 2, pp. 173-185. 



\section{Appendix A}

De grenzen en typering hebben betrekking op de gegevens in het ArbeidsmarktInformatieSysteem (AIS).

Tabel A.1

Grenzen kwalitatieve typering bedrijfssectoren

\begin{tabular}{lcccc}
\hline Typering & erg laag & laag t.o.v. & gemiddeld & hoog t.o.v. \\
& t.o.v. laag & gemiddeld & t.o.v. hoog & $\begin{array}{c}\text { erg hoog } \\
\text { Conjunctuurgevoeligheid }\end{array}$ \\
Verwachte uitbreidingsvraag (\%) jaarlijks & 0,52 & 0,59 & 1,09 & 1,36 \\
& $-2,6$ & $-1,2$ & 0,4 & 1,1 \\
\hline
\end{tabular}

Tabel A.2

Grenzen kwalitatieve typering beroepsgroepen

\begin{tabular}{lcccc}
\hline Typering & $\begin{array}{c}\text { erg laag } \\
\text { t.o.v. laag }\end{array}$ & $\begin{array}{c}\text { laag t.o.v. } \\
\text { gemiddeld }\end{array}$ & $\begin{array}{c}\text { gemiddeld } \\
\text { t.o.v. hoog }\end{array}$ & $\begin{array}{c}\text { hoog t.o.v. } \\
\text { erg hoog }\end{array}$ \\
Uitwijkmogelijkheden bedrijfssectoren & 1,14 & 1,87 & 5,27 & 8,48 \\
Substitutiemogelijkheden & 3,18 & 6,08 & 10,97 & 15,61 \\
Conjunctuurgevoeligheid & 0,41 & 0,62 & 1,14 & 1,52 \\
Verwachte uitbreidingsvraag (\%) jaarlijks & $-2,2$ & $-0,7$ & 1,1 & 1,9 \\
Verwachte vervangingsvraag (\%) jaarlijks & 2,4 & 2,9 & 3,8 & 4,6 \\
Verwachte baanopeningen (\%) jaarlijks & 2,7 & 3,3 & 4,4 & 5,5 \\
\hline Typering & geen t.o.v. & \multirow{2}{*}{ vrijwel geen } & enige t.o.v. & groot t.o.v. \\
& vrijwel geen & t.o.v. enige & groot & zeer groot \\
\hline ITKB & \multirow{2}{*}{0,94} & 0,91 & \multirow{2}{*}{0,88} & 0,78 \\
\hline
\end{tabular}

Tabel A.3

Grenzen kwalitatieve typering opleidingstypen

\begin{tabular}{|c|c|c|c|c|}
\hline Typering & $\begin{array}{l}\text { erg laag } \\
\text { t.o.v. laag }\end{array}$ & $\begin{array}{l}\text { laag t.o.v. } \\
\text { gemiddeld }\end{array}$ & $\begin{array}{l}\text { gemiddeld } \\
\text { t.o.v. hoog }\end{array}$ & $\begin{array}{c}\text { hoog t.o.v. } \\
\text { erg hoog }\end{array}$ \\
\hline Uitwijkmogelijkheden beroepsgroepen & 2,55 & 5,19 & 11,39 & 16,86 \\
\hline Uitwijkmogelijkheden bedrijfssectoren & 2,00 & 3,85 & 9,13 & 13,70 \\
\hline Conjunctuurgevoeligheid & 0,65 & 0,74 & 0,89 & 1,05 \\
\hline Verwachte instroom (\%) & 1,6 & 2,8 & 4,7 & 6,1 \\
\hline Verwachte uitbreidingsvraag (\%) & $-2,6$ & $-0,3$ & 1,9 & 3,6 \\
\hline Verwachte vervangingsvraag (\%) & 2,0 & 3,1 & 3,9 & 4,4 \\
\hline Verwachte baanopeningen (\%) & 3,3 & 4,1 & 5,2 & 6,7 \\
\hline Typering & $\begin{array}{l}\text { zeer goed } \\
\text { t.o.v. goed }\end{array}$ & $\begin{array}{l}\text { goed t.o.v. } \\
\text { redelijk }\end{array}$ & $\begin{array}{l}\text { redelijk } \\
\quad \text { t.o.v. matig }\end{array}$ & $\begin{array}{l}\text { matig t.o.v. } \\
\text { slecht }\end{array}$ \\
\hline ITA & 0,85 & 1,00 & 1,05 & 1,15 \\
\hline Typering & $\begin{array}{l}\text { zeer groot } \\
\text { t.o.v. groot }\end{array}$ & $\begin{array}{l}\text { groot t.o.v. } \\
\text { enige }\end{array}$ & $\begin{array}{l}\text { enige t.o.v. } \\
\text { vrijwel geen }\end{array}$ & $\begin{array}{l}\text { vrijwel geen } \\
\text { t.o.v. geen }\end{array}$ \\
\hline ITKP & 0,85 & 1,00 & 1,05 & 1,15 \\
\hline
\end{tabular}


Tabel A.4

Grenzen kwalitatieve typering opleidingstypen en -richtingen schoolverlatersinformatie

\begin{tabular}{lrrrr}
\hline Typering & $\begin{array}{c}\text { erg laag } \\
\text { t.o.v. laag }\end{array}$ & $\begin{array}{c}\text { laag t.o.v. } \\
\text { gemiddeld }\end{array}$ & $\begin{array}{c}\text { gemiddeld } \\
\text { t.o.v. hoog }\end{array}$ & $\begin{array}{c}\text { hoog t.o.v. } \\
\text { erg hoog }\end{array}$ \\
\hline Participatie in vervolgopleidingen studie & 3,01 & 10,53 & 22,75 & 47,93 \\
Participatie in vervolgopleidingen BBL & 1,20 & 5,39 & 16,34 & 46,25 \\
Percentage deeltijdarbeid & 5,78 & 10,66 & 35,44 & 54,62 \\
Percentage met een vast dienstverband & 50,79 & 63,43 & 83,96 & 92,96 \\
Intredewerkloosheid van 4 mnd of langer & 1,10 & 2,76 & 8,40 & 12,97 \\
Percentage werkloosheid & 0,77 & 1,79 & 4,90 & 7,33 \\
Onderbenutting & 10,93 & 19,87 & 36,98 & 55,64 \\
Functie buiten de eigen vakrichting & 7,93 & 17,16 & 30,59 & 48,80 \\
Gemiddeld bruto maandloon mavo/vmbo & 711 & 776 & 886 & 1.223 \\
Gemiddeld bruto mndloon havo/vwo/mbo & 1.126 & 1.334 & 1.518 & 1.870 \\
Gemiddeld bruto maandloon hbo & 1.828 & 1.937 & 2.072 & 2.172 \\
Gemiddeld bruto maandloon wo & 2.114 & 2.207 & 2.450 & 2.585 \\
\hline
\end{tabular}

Er worden vijf typeringen onderscheiden: erg laag, laag, gemiddeld, hoog en erg hoog. Bij de Indicator toekomstige arbeidsmarktsituatie (ITA) betreft dit: zeer goed, goed, redelijk, matig, slecht en met betrekking tot de Indicator toekomstige kans op knelpunten in de personeelsvoorziening (ITKP): zeer groot, groot, enige, vrijwel geen, geen. Voor alle variabelen, met uitzondering van de ITA, de ITKP en de ITKB, zijn grenzen bepaald op basis van de kwantielenmethode (zie ook Wieling, De Grip en Willems, 1990). Bij de kwantielenmethode worden de grenzen zodanig bepaald dat $10 \%$ in de klasse erg laag valt, $20 \%$ in laag, $40 \%$ in gemiddeld, $20 \%$ in hoog en $10 \%$ in de klasse erg hoog. Voordat een procentuele variabele wordt gekwalificeerd, wordt het percentage afgerond. Voor de grenzen voor de ITKB is de procentuele verdeling van de opleidingstypen over de typeringen die voor de ITKP gelden bepaald. Deze verdeling is opgelegd aan de knelpunten naar beroep. Als bijvoorbeeld $34 \%$ van de opleidingen gekenmerkt wordt door zeer grote knelpunten, wordt de grens tussen grote en zeer grote knelpunten bij de ITKB zodanig vastgesteld dat $34 \%$ van de beroepen ook de typering zeer grote knelpunten krijgt. 


\section{Appendix B}

Onderstaand een overzicht van de opleidingsnamen die in de uitgave De arbeidsmarkt naar opleiding en beroep tot 2008 gewijzigd zijn naar aanleiding van het commentaar van enkele onderwijsinstellingen (ROC's). Er wordt benadrukt dat er slechts sprake is van een wijziging van de benamingen van de opleidingstypen en niet van de onderliggende classificaties en opleidingscodes.

Tabel B.1

Overzicht gewijzigde opleidingsnamen

\begin{tabular}{ll}
\hline Oude naam & Nieuwe naam \\
\hline MBO landbouw en veeteelt & MBO voeding, natuur en milieu \\
MBO milieu en groene ruimte & MBO groene ruimte \\
MBO motorvoertuigentechniek & MBO motorvoertuigentechniek en tweewielers \\
MBO vervoer en logistiek & MBO vervoer \\
MBO sociaal-cultureel & MBO sociaal-pedagogisch en welzijn \\
MBO administratie & MBO administratie en logistiek \\
MBO bedrijfskunde & MBO facilitaire dienstverlening \\
MBO automatisering & MBO ICT \\
& \\
\hline
\end{tabular}

